\title{
Systematics and evolution of the needle grasses (Poaceae: Pooideae: Stipeae) based on analysis of multiple chloroplast loci, ITS, and lemma micromorphology
}

\author{
Konstantin Romaschenko, ${ }^{1,2}$ Paul M. Peterson, ${ }^{2}$ Robert J. Soreng, ${ }^{2}$ Nuria Garcia-Jacas, ${ }^{1}$ Oksana Futorna ${ }^{3}$ \\ \& Alfonso Susanna ${ }^{1}$
}

1 Laboratory of Molecular Systematics, Botanic Institute of Barcelona (CSIC-ICUB), Passeig del Migdia s.n., 08038, Barcelona, Spain

2 Department of Botany, National Museum of Natural History, Smithsonian Institution, Washington, D.C., 20013, U.S.A.

3 M.G. Kholodny Institute of Botany, National Academy of Sciences of Ukraine, 01601 Kiev, Ukraine

Author for correspondence: Paul M. Peterson, peterson@si.edu

\begin{abstract}
We conducted a molecular phylogenetic study of the tribe Stipeae using nine plastid DNA sequences (trnK-matK, matK, trnH-psbA, trnL-F, rps3, ndhF, rpl32-trnL, rps16-trnK, rps16 intron), the nuclear ITS DNA regions, and micromorphological characters from the lemma surface. Our large original dataset includes 156 accessions representing 139 species of Stipeae representing all genera currently placed in the tribe. The maximum likelihood and Bayesian analyses of DNA sequences provide strong support for the monophyly of Stipeae; including, in phylogenetic order, Macrochloa as remote sister lineage to all other Stipeae, then a primary stepwise divergence of three deep lineages with a saw-like (SL) lemma epidermal pattern (a plesiomorphic state). The next split is between a lineage (SL1) which bifurcates into separate Eurasian and American clades, and a lineage of three parts; a small Patis (SL2) clade, as sister to Piptatherum s.str. (SL3), and the achnatheroid clade (AC). The AC exhibits a maize-like lemma epidermal pattern throughout. AC consists of a core clade of Austral-Eurasian distribution and a "major American clade" of North and South American distribution. The base chromosome number for Stipeae is somewhat ambiguous but based on our survey it seems most likely to be $x=11$ or 12 . Our phylogenetic hypothesis supports the recognition of the following genera and groups (listed by region): Eurasia-Achnatherum, "Miliacea group", "Neotrinia" (monotypic), Orthoraphium (monotypic), Patis (also 1 from North America), Piptatherum s.str., Psammochloa (monotypic), Ptilagrostis, Stipa, "Timouria group", and Trikeraia; Mediterranean-Ampelodesmos (monotypic), Celtica (monotypic), Macrochloa (monotypic), and "Stipella-Inaequiglumes group"; Australasia - Anemanthele (monotypic), and Austrostipa; North America (NA) - "Eriocoma group", Hesperostipa, Oryzopsis (monotypic), Piptatheropsis, "Pseudoeriocoma group", and "Stillmania" (monotypic); South America-Aciachne, Amelichloa (also NA), Anatherostipa (s.str.), Jarava (polyphyletic), Lorenzochloa, Nassella (also NA), Ortachne, Pappostipa (also NA), and Piptochaetium (also NA). Monophyly of Phaenospermateae including Duthieinae is demonstrated, and its inclusion within or treatment as sister to Stipeae is rejected.
\end{abstract}

Keywords biogeography; evolution; grasses; lemma micromorphology; molecular systematics; phylogeny; plastid DNA sequences; Poaceae; Stipeae

Supplementary Material Appendices 1 to 3 (in the Electronic Supplement) and the alignments are available in the Supplementary Data section of the online version of this article (http://ingentaconnect.com/content/iapt/tax).

\section{INTRODUCTION}

Peripheral Stipeae, clarification of what is in and what is outside the tribe. - Stipeae Martinov are cool-season or temperate $\mathrm{C}_{3}$ grasses placed in subfamily Pooideae Benth. (GPWG, 2001). We estimate that the Stipeae s.str. include between 572 and 670 species with the number varying depending on how finely the Asian taxa are divided. The broadest molecular studies in Pooideae (GPWG, 2001; Davis \& Soreng, 2007; Soreng \& al., 2007; Bouchenak-Khelladi \& al., 2008; Schneider \& al., 2009) place the origin of Stipeae after the separation of Brachyelytreae Ohwi, Lygeeae J. Presl, and Nardeae W.D.J. Koch, among the remaining tribes Phaenospermateae Renvoize \& Clayton s.l. (including Duthieinae Pilg. ex Potztal), Meliceae Link ex Endl. plus Brylkinieae Tateoka, Diarrheneae
C.S. Campb., and core Pooideae (Brachypodieae Harz, Bromeae Martinov plus Hordeeae Martinov (= Triticeae Dumort.), Poeae R. Br. including Aveneae Dumort.). Although Diarrheneae are usually resolved as sister to core Pooideae, the exact phylogenetic relationships of Stipeae within this set has varied among studies. A few genera placed in Stipeae s.l. clearly do not belong there: Milium L. (Clayton \& Renvoize, 1986), Cyathopus Stapf, and Dichelachne Endl. (Tzvelev, 1989) have been resolved within Poeae based on molecular data (Döring, 2009; Schneider \& al., 2009; Soreng \& al., 2007), and Streptachne R. Br. (Tzvelev, 1989) has been accepted by other agrostologists as a synonym of Aristida L. in Aristidoideae Caro.

Subtribe Duthieinae is sometimes placed in Aveneae, Stipeae, or Phaenospermateae. In its broadest current sense Duthieinae includes: Anisopogon R. Br., Danthoniastrum (J. Holub) 
Holub, Metcalfia Connert, Pseudodanthonia Bor \& C.E. Hubb., Sinochasea Keng, Duthiea Hack., and Stephanachne Keng (Baum, 1973; Clayton \& Renvoize, 1986; Holub, 1998; Wu \& Phillips, 2006; Soreng \& al., 2011). Based on molecular data, and morphological extension of that, Megalachne Steud. (Döring, 2009) and Podophorus Phil. should be placed in Poeae (Clayton \& Renvoize, 1986; Soreng \& al., 2011), rather than in Duthieinae (Soreng \& al., 2003). Uncertainty concerning the relationships of the American and Chinese elements of subtribe Duthieinae (sensu Clayton \& Renvoize, 1986), led Soreng \& al. (2003) and Wu \& Phillips (2006) to place the genera of this subtribe within Stipeae, and accept Phaenospermateae as a monotypic tribe. Although accumulating molecular DNA data support placing Duthieinae in Phaenospermateae, the relationship of Duthieinae and Phaenospermateae to Stipeae remains poorly resolved and controversial (GPWG, 2001; Soreng \& al., 2003, 2011; Davis \& Soreng, 2007, 2010; Romaschenko \& al., 2008, 2010; Schneider \& al., 2009). Anisopogon was added to Duthieinae (Soreng \& al., 2011) based on molecular data (GPWG, 2001; Davis \& Soreng, 2007, 2010).

Morphological inferences. - Stipeae s.str. (excluding the above-mentioned elements and ignoring Ampelodesmos Link) are mostly tussock-forming grasses characterized by having single-flowered spikelets without rachilla extensions that disarticulate above the glumes; florets with a distinct, sometimes sharp, often bearded callus, lemmas that are rounded on the back, (3-)5-9-nerved, and often concealing the palea (if the palea is exposed when the floret is closed, then the palea is coriaceous), terminally awned (or from between short lobes) where the awn is the result of fusion between the central and two lateral vascular traces, the awn usually geniculate and twisted in the proximal segment and sometimes caducous, plumose or scabrous; flowers with three, sometimes two, linear lodicules that are slightly indurate at maturity and glabrous (with venation weaker than in other subfamilies but often more distinct than in other Pooideae), often penicillate anthers tips, glabrous ovaries, caryopses with a long-linear hilum, small embryos with compound starch and no lipid; and small-sized chromosomes with a base number $x=7,8$, $9,10,11$, or 12 , for which the ancestral base number is uncertain. Unlike most Pooideae genera, the surfaces of the leaves occasionally have unicellular microhairs (Barkworth, 2007; Clayton \& Renvoize, 1986; Soreng \& Davis, 1998).

The number of genera accepted in the Stipeae varies widely in modern treatments. Tzvelev $(1976,1989)$ accepted four genera in the former Soviet Union and 18 in the World, Clayton \& Renvoize (1986) accepted nine in the World, Barkworth (2007) accepted 13 in the U.S.A. and Canada, and Soreng \& al. (2003) list 18 accepted genera of Stipeae for the New World (see Table 1). These genera (excluding Ampelodesmos, which when included in Stipeae is placed in subtribe Ampelodesminae), represent Stipeae s.str. or the "core Stipeae". Generic boundaries among the genera in the Stipeae are problematic, especially within Achnatherum P. Beauv., Jarava Ruiz \& Pav., Stipa L., Oryzopsis Michx., and Piptatherum P. Beauv. Difficult and controversial delimitations among these led agrostologists to adopt a broad concept of the genus Stipa to encompass all of the currently accepted genera except Oryzopsis, Aciachne Benth., and Piptochaetium J. Presl in the New World (Spegazzini, 1901; Hitchcock, 1935, 1951) and to split Piptatherum in the Old World from New World Oryzopsis s.l. (Freitag, 1975, 1985). Various studies were performed that described new genera and emend generic limits (Parodi, 1947, 1960; Barkworth, 1983, 1990, 1993; Jacobs \& Everett, 1996; Peñailillo, 1996, 2002, 2003, 2005; Rojas, 1997; Torres, 1997a, b, c; Barkworth \& Torres, 2001; Cialdella \& Giussani, 2002; Vázquez \& Barkworth, 2004; Arriaga \& Barkworth, 2006; Cialdella \& al., 2007; Romaschenko \& al., 2008, 2010; Barber \& al., 2009).

Phylogenetic inferences for Stipeae based on traditional morphological characters are few. Based on morphological features the most comprehensive review was made by Tzvelev (1977) where phylogenetic weight was assigned to such characters as shape of the lemma and callus, and development of awn indumentum. Tzvelev's general phylogenetic system suggested there were two major lineages: (1) Stipa s.str. (including long lanceolate lemmas, strongly developed awn indumentums, and sharp callus) and; (2) Piptatherum (including short, hairless lemmas with a caducous awn, and a blunt callus). Piptatherum was thought to have originated from more primitive Achnatherumlike species, whereas Ptilagrostis Griseb. and Achnatherum chinense (Hitchc.) Tzvelev were considered to be intermediate taxa between Achnatherum and Stipa s.str., and Achnatherum and Piptatherum, respectively. Piptochaetium and Nassella (Trin.) E. Desv. were considered to be close relatives, and Eriocoma Nutt. was thought to be a vicariant branch of Piptatherum in the New World. Over the years most of the American species of Stipa s.l. were placed in endemic New World genera, such as Anatherostipa (Hack. ex Kuntze) Peñailillo (Peñailillo, 1996) and Jarava, or into two genera (Achnatherum and Piptatherum) thought to be shared with Asia.

Thomasson $(1978,1980,1981,1982,1985)$ was first to document the phylogenetic importance of the lemma epidermal pattern in Stipeae. Barkworth \& Everett (1987) used this information to delineate hypothetical relationships among genera, pointing out that Stipa and Piptatherum have elongated lemma epidermal cells with sinuous lateral walls (pattern also revealed in Miocene-dated spikelets of the fossil genus Berriochloa M.K. Elias; Thomasson, 1978, 1982, 1985), and that Achnatherum and Austrostipa S.W.L. Jacobs \& J. Everett have short lemma epidermal cells with slightly sinuous to strait lateral walls. However, Barkworth \& Everett (1987) followed Tzvelev (1977) in emphasizing the shape of the lemma and callus and development of awn indumentum rather than lemma epidermal pattern, and therefore postulated a similar phylogenetic history. Hesperostipa (M.K. Elias) Barkworth and the "Obtusa group" of Parodi (1946; included in Anatherostipa), and Nassella and Piptochaetium sensu Tzvelev were thought to be two pairs of closely related genera.

Molecular inferences. - Evolutionary relationships within Stipeae based on studies of molecular characters have not been clearly or fully elucidated (Jacobs \& al., 2000, 2007; Barkworth \& al., 2008; Romaschenko \& al., 2008, 2010), and these as well as those based on morphology remain controversial (Barkworth \& Everett, 1987; Barkworth, 1993; Chiapella, 2008). Prior to the study of Romaschenko \& al. (2010), only a 
Table 1. Comparison of recent classifications of genera and phylogenetically isolated lineages in the tribes Stipeae and Ampelodesmeae with our proposed arrangement. " $y$ " = accepted, otherwise the genus in which the taxon is placed is specified (qualified by "presumably" where a genus was published later and the taxonomy was not explicit as to the species' placement in the source); parentheses enclose estimated numbers of species, if given in the source, or determinable from that; "p.p." = pro parte; a non-italicized "group" name implies the name is informal here and an italicized "group" name implies the published genus has not been formally emended to include some elements included here; "n/a" indicates the genus or group was neither within geographic purview of, nor otherwise mentioned in, the source; FNA= Barkworth \& al. (2007).

\begin{tabular}{|c|c|c|c|c|c|c|}
\hline $\begin{array}{l}\text { Genus (or group isolated from a genus in } \\
\text { which it has been included) }\end{array}$ & $\begin{array}{l}\text { Tzvelev } \\
(1976)\end{array}$ & $\begin{array}{l}\text { Clayton } \\
\text { \& Renvoize } \\
(1986)\end{array}$ & $\begin{array}{l}\text { Tzvelev } \\
(1989)\end{array}$ & $\begin{array}{l}\text { Soreng \& al. } \\
(2003)\end{array}$ & $\begin{array}{l}\text { Barkworth } \\
\& \text { al. (2007) }\end{array}$ & $\begin{array}{l}\text { Our opinion, } \\
\text { here }\end{array}$ \\
\hline Achnatherum P. Beauv. & y $(20)$ & Stipa & y $(20)$ & y (36) & $\begin{array}{l}\text { y (27 FNA na- } \\
\text { tive, } 7 \text { Mexico, } \\
1 \text { New Zea- } \\
\text { land, } 21 \text { Old } \\
\text { World; ca. } 56 \\
\text { in total) }\end{array}$ & y, p.p. (21) \\
\hline
\end{tabular}

Aciachne Benth.

Amelichloa Arriaga \& Barkworth

Ampelodesmos Link

Anatherostipa (Hack. ex Kuntze) Peñailillo

Anemanthele Veldkamp

Austrostipa S.W.L. Jacobs \& J. Everett

Celtica F.M. Vázquez \& Barkworth

"Eriocoma Nutt. group"

Hesperostipa (M.K. Elias) Barkworth

Jarava Ruiz \& Pav.

Lorenzochloa Reeder \& C. Reeder

Macrochloa Kunth
"Miliacea group" (former Piptatherum sect.)
Nassella (Trin.) E. Desv.
"Neotrinia" (former Achnatherum sect.)

Ortachne Nees ex Steud.

Orthoraphium Nees

Oryzopsis Michx.

Pappostipa (Speg.) Romasch., P.M. Peterson \& Soreng

$\begin{array}{ll}\text { n/a } & \text { Stipa } \\ \text { n/a } & \text { Stipa } \\ \text { n/a } & \text { y (15) } \\ \text { Achnatherum } & \text { Stipa } \\ \text { sect. Neotrinia } & \\ \text { n/a } & \text { y (3) } \\ \text { n/a } & \text { Stipa } \\ \text { n/a } & \text { y (35) } \\ \text { n/a } & \text { presumably } \\ & \text { in Stipa }\end{array}$

$\mathrm{n} / \mathrm{a}$

$\mathrm{n} / \mathrm{a}$

$\mathrm{n} / \mathrm{a}$

y (1)
presumably
in Stipa

$y$, tribe Poeae

(1)

presumably in Stipa

$\mathrm{n} / \mathrm{a}$

$\mathrm{n} / \mathrm{a}$

$\mathrm{n} / \mathrm{a}$

$\mathrm{n} / \mathrm{a}$

$\mathrm{n} / \mathrm{a}$

$\mathrm{n} / \mathrm{a}$

$\mathrm{n} / \mathrm{a}$ presumably in Stipa

presumably in Stipa

presumably in Stipa

Oryzopsis

presumably in Stipa

Stipa

Ortachne

y (1)

y (3) y (1)

y (3)

presumably

in Stipa

$y$, tribe

Ampelodesmeae (1)

presumably in Stipa

presumably in Stipa

presumably in Stipa

Stipa

presumably

in Stipa

Stipa

y (59)

$\mathrm{y}(50)$

Ortachne

$\mathrm{n} / \mathrm{a}$ y (3)

$\mathrm{y}$, tentatively, needs further study (5)

$\mathrm{y}$, tentatively in subtribe Ampelodesminae (1)

not monophyletic, p.p. typic (8)

y, p.p. monophyletic (30)

y (1) nested within Anatherostipa p.p. non-typic, needs further study

Stipa y (2)

Piptatherum

y (10)

Achnatherum

Piptatherum

y (1)

y (1)

y (115)

Piptatherum

y (2)

y (117)

y (1)

y (2)

y (3)

$\mathrm{n} / \mathrm{a}$

y (2)

$\mathrm{n} / \mathrm{a}$

$\mathrm{n} / \mathrm{a}$

y (1)

y (1)

y (1)

$\mathrm{y}(1)$

presumably

Jarava

Jarava 
Table 1. Continued.

\begin{tabular}{|c|c|c|c|c|c|c|}
\hline $\begin{array}{l}\text { Genus (or group isolated from a genus in } \\
\text { which it has been included) }\end{array}$ & $\begin{array}{l}\text { Tzvelev } \\
(1976)\end{array}$ & $\begin{array}{l}\text { Clayton } \\
\text { \& Renvoize } \\
(1986)\end{array}$ & $\begin{array}{l}\text { Tzvelev } \\
(1989)\end{array}$ & $\begin{array}{l}\text { Soreng } \\
\& \text { al. }(2003)\end{array}$ & $\begin{array}{l}\text { Barkworth } \\
\& \text { al. (2007) }\end{array}$ & $\begin{array}{l}\text { Our opinion, } \\
\text { here }\end{array}$ \\
\hline Patis Ohwi & $\mathrm{n} / \mathrm{a}$ & Stipa & y (1) & $\begin{array}{l}\text { (1 in FNA in } \\
\text { Piptatherum })\end{array}$ & $\begin{array}{l}\text { ( } 1 \text { in FNA in } \\
\text { Piptatherum })\end{array}$ & y (3) \\
\hline $\begin{array}{l}\text { Piptatheropsis Romasch., P.M. Peterson \& } \\
\text { Soreng }\end{array}$ & $\mathrm{n} / \mathrm{a}$ & Oryzopsis & $\begin{array}{l}\text { presumably } \\
\text { in Stipa }\end{array}$ & Piptatherum & Piptatherum & y (5) \\
\hline Piptochaetium J. Presl & $\mathrm{n} / \mathrm{a}$ & $\mathrm{y}(30)$ & y $(20)$ & y (35) & y (27) & y (35) \\
\hline Psammochloa Hitchc. & $\mathrm{n} / \mathrm{a}$ & $\mathrm{y}(1)$ & $\mathrm{y}(1)$ & $\mathrm{n} / \mathrm{a}$ & $\mathrm{n} / \mathrm{a}$ & $\mathrm{y}(1)$ \\
\hline $\begin{array}{l}\text { Pseudoericoma group (clambering spp. for- } \\
\text { merly of Achnatherum and Jarava) }\end{array}$ & $\mathrm{n} / \mathrm{a}$ & $\begin{array}{l}\text { presumably } \\
\text { in Stipa }\end{array}$ & $\begin{array}{l}\text { presumably } \\
\text { in Stipa }\end{array}$ & $\begin{array}{l}\text { Achnatherum, } \\
\text { Jarava }\end{array}$ & $\begin{array}{l}\text { Achnatherum, } \\
\text { Jarava }\end{array}$ & $\begin{array}{l}\text { y, Jarava } \\
\text { p.p. \& } \\
\text { Achnatherum } \\
\text { p.p. (7 min.) }\end{array}$ \\
\hline $\begin{array}{l}\text { "Stillmania" (formerly in Achnatherum or } \\
\text { Stipa) }\end{array}$ & $\mathrm{n} / \mathrm{a}$ & $\begin{array}{l}\text { presumably } \\
\text { in Stipa }\end{array}$ & unknown & Achnatherum & Achnatherum & $\mathrm{y}(1)$ \\
\hline Stipa L. & y (300) & $\mathrm{y}(300)$ & y (300) & $\mathrm{y}$ & y (200) & y (110 min.) \\
\hline $\begin{array}{l}\text { "Stipella-Inaequiglumes group" } \\
\text { (former Stipa sects.) }\end{array}$ & $\begin{array}{l}\text { Stipa sect. } \\
\text { Stipella } \text { and } \\
\text { Inaequiglumes }\end{array}$ & Stipa & Stipa & $\mathrm{a} / \mathrm{a}$ & $\mathrm{n} / \mathrm{a}$ & $\mathrm{y}(2)$ \\
\hline $\begin{array}{l}\text { "Timouria Roshev. group" (includes some } \\
\text { Achnatherum spp.) }\end{array}$ & $\begin{array}{l}\text { Achnatherum } \\
\text { sect. Timouria }\end{array}$ & Stipa & Achnatherum & $\mathrm{n} / \mathrm{a}$ & $\mathrm{n} / \mathrm{a}$ & y (5) \\
\hline Trikeraia Bor & $\mathrm{n} / \mathrm{a}$ & $\mathrm{y}(2)$ & y (2) & $\mathrm{n} / \mathrm{a}$ & $\mathrm{n} / \mathrm{a}$ & y (3) \\
\hline
\end{tabular}

${ }^{a}$ Genera placed in Stipeae by only one of the compared classifications are exempted from the table since they are now understood to belong to other tribes: Streptachne (=Aristida)—Aristideae; Metcalfia_Phaenospermateae; Cyathopus, Dichelachne, Megalachne, Milium, Podophorus—Poeae s.l.

small fraction of the Stipeae s.str. genera and generic diversity were sampled, and outgroup sampling remained poor.

Ampelodesmos, which is very different from Stipeae s.str. in gross morphology of the spikelet, but similar in anatomy and cytology to members of this tribe (Decker, 1964), appears from molecular data to be nested in Stipeae (Davis \& Soreng, 2007, 2010; Hsiao \& al., 1999; Romaschenko \& al., 2008, 2010; Soreng \& Davis, 1998). The genus has recently been included in Stipeae (Barkworth, 2007), transferred into the genus Stipa (Columbus \& Smith, 2010), and is sometimes placed in the monotypic subtribe Ampelodesminae Conert (Soreng \& al., 2003, 2011).

In a series of morphological studies (Barkworth, 1990, 1993; Barkworth \& Torres, 2001; Cialdella \& Giussani, 2002) and in a phylogenetic study using molecular characters (Jacobs $\&$ al., 2000), Nassella and Piptochaetium were found to be sister genera. In more recent molecular phylogenetic analyses based on nrDNA ITS sequences, Jacobs \& al. (2007) found that the Piptatherum-Oryzopsis complex along with Stipa s.str., Ampelodesmos, Anisopogon, Hesperostipa, and Piptochaetium were among early diverging lineages; Austrostipa was depicted as a derived clade with Anemanthele Veldkamp embedded; and Nassella was more closely related to Jarava than to Piptochaetium (Cialdella \& al., 2007). However, there was little statistical support for this structure and much polyphyly of genera was evident in these trees.

In a phylogenetic analysis of 14 genera of Stipeae using four plastid loci, Cialdella \& al. (2010) found only three monophyletic genera, Austrostipa, Hesperostipa, and Piptochaetium. Their primary focus was to elucidate relationships of Aciachne and Amelichloa Arriaga \& Barkworth, both portrayed as paraor polyphyletic.

In a combined analysis of ITS and four plastid loci (Romaschenko \& al., 2008), Stipa s.str. and Piptatherum, along with Ampelodesmos, Piptochaetium, Anatherostipa, Hesperostipa, and Ptilagrostis were found to lie among the poorly resolved sets of basal lineages of Stipeae that share the lemma epidermal pattern of elongate cells with sinuous lateral walls. We identified this lemma epidermal pattern as "saw-like" because the sidewalls of the lateral cells have a serrate appearance (Romaschenko \& al., 2008, 2010). This contrasted sharply with the phylogenetic scheme proposed by Tzvelev (1977). The remainder of the Stipeae genera sampled were resolved in a well-supported achnatheroid clade consisting of: (1) a "major American clade" containing New World Achnatherum, Jarava s.str. (excluding species of the former Stipa subg. Pappostipa Speg., all of which were placed within Jarava by Peñailillo, 2003, and elevated to generic status by 
Romaschenko \& al., 2008, as Pappostipa (Speg.) Romasch., P.M. Peterson \& Soreng), and Nassella with Amelichloa nested within it; and (2) a core achnatheroid clade containing Austrostipa and Asian species of Achnatherum embedded with Eurasian species of Piptatherum (Romaschenko \& al., 2010). We identified this pattern as "maize-like" because it resembles the surface of an ear of corn by having short fundamental cells with straight sidewalls and square to rounded, closely placed silica bodies (Romaschenko \& al., 2008, 2010).

Based on five plastid and nuclear ITS sequences, Romaschenko \& al. (2010) conducted a molecular phylogenetic study of all 21 genera of Stipeae. They presented a stepwise model for the evolution of Stipeae comprising two initial deep bifurcations or splits followed by two further bifurcations, all highly correlated with geography. They found Macrochloa Kunth to be sister to all other Stipeae, Achnatherum and Piptatherum to be polyphyletic, and provided support for recognizing the following monophyletic genera: Achnatherum s.str., Aciachne, Amelichloa, Austrostipa, Hesperostipa, Jarava s.str., Ortachne Nees ex Steud., Pappostipa, Piptatherum s.str., Piptochaetium, Ptilagrostis s.str., Stipa s.str., and Trikeraia Bor.

Using four plastid regions, Romaschenko \& al. (2011) conducted a phylogenetic analysis of the short-spikeleted species of the Stipeae. They recognized a Eurasian Piptatherum clade, a new North American genus, Piptatheropsis Romasch., P.M. Peterson \& Soreng, and resurrected Patis Ohwi to include three species, two from Eurasia and one from North America.

The main objectives of the present paper are to provide a better resolved and more highly supported phylogenetic hypothesis for the currently accepted genera and infrageneric groups within Stipeae compared to our previous study (Romaschenko $\&$ al., 2010). Particular effort is made to investigate the close relationships among the American genera Hesperostipa, Piptochaetium, and Anatherostipa that was suggested by Thomasson $(1978,1982,1985)$ based on a study of lemma epidermal features. We add four plastid gene regions ( $r p s 3$, rpl32-trnL, rps16trnK, rpsl6 intron) to those we used previously ( $\operatorname{trnK} \mathrm{K}-\mathrm{mat} K$, $m a t K, \operatorname{trn} H-p s b A, \operatorname{trn} L-F, n d h F)$. We significantly expand our earlier survey of Stipeae by sampling an additional 65 species including some of uncertain taxonomic position. We test the monophyly of the achnatheroid clade and its correlation with specialized lemma epidermal anatomy, and test the monophyly of the remaining Stipeae lineages (excluding Macrochloa) that lack the achnatheroid lemma epidermal anatomy. We compare phylogenetic trees based on plastid and ITS datasets, discuss previous molecular and morphological studies where appropriate, correlate lemma micromorphological characters and chromosome base numbers with our hypotheses based on our phylograms, interpret biogeographical relationships, and evaluate the phylogenetic signal of plastid inversions and indels.

\section{MATERIALS AND METHODS}

Taxon sampling. - The Stipeae sample (voucher information and GenBank numbers are given in Appendix 1 in the Electronic Supplement) consists of all 23 to 26 accepted genera (Soreng \& al., 2003, 2011), has enhanced coverage within major infrageneric lineages of polyphyletic genera detected in our previous studies (Romaschenko \& al., 2008, 2010), and has improved focus on the taxonomic and geographical diversity within the tribe. At least two exemplars from each non-monotypic genus and internal group previously resolved have been selected to facilitate a more accurate interpretation of the generic concepts in the tribe. The total dataset of 156 accessions representing 139 species comprises 7279 aligned nucleotide positions, $6639 \mathrm{bp}$ from the plastid data, and $640 \mathrm{bp}$ nuclear ribosomal ITS data (Table 2). Nine hundred and fifty sequences are newly reported to GenBank (Appendix 1). We included the type species of all infrageneric groups and genera sampled. In order to determine the phylogenetic limits of Stipeae and its relationships with other tribes we included six of seven peripheral genera currently placed in Phaenospermateae (Schneider \& al., 2009; Soreng \& al., 2011), some of which have been classified within Stipeae (Avdulov, 1931; Tzvelev, 1977; Wu \& Phillips, 2006), and Brylkinia F. Schmidt (Brylkinieae-Meliceae), Triniochloa Hitchc.

Table 2. Summary of nine plastid regions and nrDNA ITS used in this study.

\begin{tabular}{|c|c|c|c|c|c|c|c|c|c|c|c|}
\hline & $\begin{array}{l}\text { trnK- } \\
\text { matK }\end{array}$ & matK & $\begin{array}{l}\text { trnH- } \\
\text { psbA }\end{array}$ & $\operatorname{trn} L-F$ & rps3 & $n d h F$ & $\begin{array}{l}\text { rpl32- } \\
\text { trnL }\end{array}$ & $\begin{array}{l}\text { rps16- } \\
\text { trnK }\end{array}$ & $\begin{array}{l}\text { rps } 16 \\
\text { intron }\end{array}$ & $\begin{array}{l}\text { Plastid } \\
\text { dataset }\end{array}$ & ITS \\
\hline Number of taxa & 152 & 146 & 155 & 128 & 151 & 151 & 146 & 151 & 153 & 156 & 151 \\
\hline Aligned sequence length (SLal) & 589 & 555 & 663 & 754 & 688 & 783 & 954 & 814 & 839 & 6639 & 640 \\
\hline Number of excluded characters & 51 & 0 & 68 & 78 & 0 & 0 & 192 & 9 & 47 & 447 & 66 \\
\hline VC/SL (\% variability) & 31.0 & 26.5 & 24.3 & 38.4 & 20.6 & 41.0 & 56.6 & 44.8 & 29.3 & 35.4 & 65.4 \\
\hline VC/SLal (\% variability) & 29.7 & 26.5 & 20.0 & 33.0 & 20.6 & 41.0 & 43.0 & 39.4 & 26.0 & 32.0 & 59.1 \\
\hline Tree length & 152 & 115 & 136 & 153 & 183 & 505 & 528 & 348 & 241 & 2514 & 1475 \\
\hline
\end{tabular}

Best-fit model of nucleotide substitution according to Akaike information criterion 
(Meliceae), Diarrhena P. Beauv. (Diarrheneae), and Dielsiochloa Pilg. (Poeae). Brachyelytrum erectum (Schreb.) P. Beauv., Nardus stricta L., and Lygeum spartum L. were included as outgroups based on their well-documented early diverging positions in subfamily Pooideae (Hilu \& al., 1999; GPWG, 2001; Soreng \& al., 2003, 2007, 2011; Davis \& Soreng, 2007; Bouchenak-Khelladi \& al., 2008; Schneider \& al., 2009).

DNA extraction, amplification, and sequencing. - The plant tissue was disrupted using Qiagen TissueLyser, and DNA was isolated using a BioSprint 96 DNA Plant Kit (Qiagen, Valencia, California, U.S.A.). For amplification, the genomic DNA was combined with $1 \times$ reaction buffer $(200 \mathrm{mM}$ Tris- $\mathrm{HCl}$, $500 \mathrm{mM} \mathrm{NH}_{4}$; Bioline Biolase Taunton, Madison, Wisconsin, U.S.A.) without $\mathrm{Mg}^{++}, 2 \mathrm{mM} \mathrm{MgCl}, 200 \mathrm{mM}$ dNTPs, $1.5 \mu \mathrm{l}$ of Taq polymerase (Bioline Biolase Taunton), and $40 \mathrm{pmol} / \mu \mathrm{l}$ each of forward and reverse primers.

We targeted nine chloroplast DNA regions from the large single copy (LSC) and the small single copy (SSC) regions of the genome: $\operatorname{trnK}$-matK (intron, LSC), matK (coding region, LSC), $\operatorname{trn} H^{G U G}-(r p s 19)-p s b A$ (coding region, spacer, LSC), $\operatorname{trnL}$-trnF (intron, spacer, LSC), rps3 (coding region, LSC), $n d h F$ (coding region, SSC), rpl32-trnL ${ }^{U A G}$ (spacer, SSC), rps 16$\operatorname{trnK}$ (spacer, LSC), and rps16 (intron, LSC). The trnK-5'matK intergenic spacer (IGS) was amplified and sequenced using the primers trnK3914F (Johnson \& Soltis, 1995) and trnK660SR (Romaschenko \& al., 2008). The primers trnK660SF and matK1412SR (Romaschenko \& al., 2008) were used to amplify the $5^{\prime}$-end portion (555 bp) of matK. The trn $H^{G U G}$-psbA region was amplified with primers trnHf ${ }^{\mathrm{GUG}}$ (Tate \& Simpson, 2003) and psbA3f (Sang \& al., 1997). In Stipeae, as in most monocots (Wang \& al., 2008), this region encompasses the entire copy of the rps 19 gene embedded between the $\operatorname{trn} H^{G U G}$ and $p s b A$ genes. Within Stipeae the lengths and variability (\%) of the components of this region are: $\operatorname{trnH}^{G U G}$-rps19 IGS (inverted repeat, $\left.\mathrm{IR}_{\mathrm{A}}\right)$-195 bp (5.1\%), rps19 $\left(\mathrm{IR}_{\mathrm{A}}\right)-216 \mathrm{bp}(4.1 \%)$, and rps19-psbA IGS (LSC) - 165 bp (22\%). The $t r n H^{G U G}-p s b A$ region has been used for phylogenetic inferences (Shaw \& al., 2005, 2007) and barcoding purposes (Kress \& al., 2005, 2009; Kress \& Erickson, 2009).

The $\operatorname{trn} L-\operatorname{trn} F$ region which includes the $\operatorname{trn} L$ intron, the $3^{\prime} \operatorname{trn} L$ exon, and the $\operatorname{trn} L-\operatorname{trnF}$ intergenic spacer, was amplified using primers $5^{\prime} \operatorname{trn} \mathrm{L}^{\mathrm{UAA}}(\mathrm{f})$ and $\operatorname{trnF}^{\mathrm{GAA}}(\mathrm{c})$ (Taberlet \& al., 1991). The rps3 gene was amplified and sequenced using primers rps3C29F and rps3C697R (Peterson \& al., 2010a, b). Variability rate and ease of amplification make it suitable for phylogenetic study, especially when working with older herbarium specimens. For the $n d h F$ gene we amplified and sequenced the variable 3 '-end (783 bp) with the primers ndhF1311F and ndhF2091R (Romaschenko \& al., 2010).

The region rpl32-trn $L^{U A G}$ was amplified and sequenced with primers trnL ${ }^{\mathrm{UAG}}$ and rpl32-F (Shaw \& al., 2007). The sequences contain the entire rpl32-trn $L^{U A G}$ IGS and a small portion of the $t r n L^{U A G}$ gene. The rps16-trnK IGS was amplified and sequenced with rpS16-900F and 3914PR primers (Peterson $\&$ al., 2010a, 2010b). Since the rpS16-900F primer is placed at the 3 -end of rps 16 intron the amplified region contains the entire 3'rps16 exon and rps16-trnK IGS. For amplification of the rps16 intron the primers rpS16R and $\mathrm{rpS} 16 \mathrm{~F}$ were used (Peterson \& al., 2010a, b).

The amplification parameters that we found to be effective across a wide range of the taxa for the plastid regions were: initial denaturation phase of $4 \mathrm{~min}$ at $94^{\circ} \mathrm{C}$; followed by 35 cycles of denaturation at $94^{\circ} \mathrm{C}$ for $40 \mathrm{~s}$, annealing phase at $50^{\circ} \mathrm{C}-56^{\circ} \mathrm{C}$ for $40 \mathrm{~s}$, extension phase at $72^{\circ} \mathrm{C}$ for $1 \mathrm{~min} 30 \mathrm{~s}$, and final extension at $72^{\circ} \mathrm{C}$ for $10 \mathrm{~min}$. We used $50^{\circ} \mathrm{C}-51^{\circ} \mathrm{C}$ of primer annealing temperature for all coding plastid regions. The entire nuclear ribosomal ITS region was amplified using primers ITS4 (White \& al., 1990) and ITS5A (Stanford \& al., 2000 ) with the following thermocycler settings: $4 \mathrm{~min}$ at $94^{\circ} \mathrm{C}$; followed by 35 cycles of $94^{\circ} \mathrm{C}$ for $30 \mathrm{~s}, 55^{\circ} \mathrm{C}$ for $30 \mathrm{~s}, 72^{\circ} \mathrm{C}$ for $1 \mathrm{~min} 20 \mathrm{~s}$, and a final extension at $72^{\circ} \mathrm{C}$ for $10 \mathrm{~min}$.

All PCR products were cleaned with ExoSAP-IT (USB, Cleveland, Ohio, U.S.A.). DNA sequencing was performed with BigDye Terminator Cycle Sequencing v.3.1 (PE Applied Biosystems, Foster City, California, U.S.A.) according to the following parameters: $80^{\circ} \mathrm{C}, 5 \mathrm{~min} ; 25$ or 30 cycles of $95^{\circ} \mathrm{C}$ for $10 \mathrm{~s}, 50^{\circ} \mathrm{C}$ for $5 \mathrm{~s}$ and $60^{\circ} \mathrm{C}$ for $4 \mathrm{~min}$. Sequenced products were analyzed on an ABI PRISM 3730 DNA Analyzer 7900HT (ABI). All regions except rpl32-trnL, rps16 intron, and $3^{\prime} r p s$ 16-5'trnK were sequenced in one direction. Relatively short regions (500-750 bp) covered by our primers were easily interpreted allowing us to accumulate sequences from different parts of the genome for phylogenetic inference (Shaw \& al., 2005, 2007). The rpl32-trnL, rps16 intron, and 3'rps 16- 5'trnK were sequenced in both directions and the program Sequencher v.4.8 (Gene Codes Corp., Ann Arbor, Michigan, U.S.A., 19912007) was employed to produce the contig sequence for the entire region.

Phylogenetic analyses. - Sequences alignment was done manually using BioEdit v.7.0.5.3 (Hall, 1999). The indels, minute inversions, and other regions for which alignment was considered ambiguous, were excluded from the analyses. OLIGO v.7.33 (Rychlik, 2009) was implemented to investigate the nature of putative minute inversions detected in the rpl32-trnL IGS (between 671-676 bp of aligned sequence) and $r p s 19-p s b A$ IGS of the $t r n H-p s b A$ region. The objectives were to define these minute inversions and determine if they were reversed point mutations or constitute stable loops of the single-stranded hairpin formations (Downie \& Palmer, 1992; Kelchner \& Wendel, 1996; Kim \& Lee, 2005; Bain \& Jansen, 2006; Catalano \& al., 2009; Lehtonen \& al., 2009). The results of this analysis were used as additional characters or support for the putative phylogenetic groups (see Appendix 2 in the Electronic Supplement). These mutations were plotted on the plastid phylogram (Fig. 1). The amount of excluded data for each region is presented in Table 2. No data was excluded from $m a t K, r p s 3$, and $n d h F$. All gaps were treated as missing data.

We conducted maximum likelihood and Bayesian analyses to infer phylogenies. The maximum likelihood analysis was conducted with the program GARLI v.0.951 (Zwickl, 2006). Bayesian and maximum likelihood analyses yielded trees with visually similar topology, i.e., the trees are visually the same, but some branch lengths could differ minutely. A test run of Bayesian analysis for the combined plastid dataset under the 
single GTR $+\mathrm{G}$ model yielded the same topology and posterior probability (PP) values as the Bayesian analysis for a partitioned dataset performed under models suggested by MrModeltest v.1.1b (Nylander, 2002) for separate regions. The Akaike information criterion models are indicated in Table 2 (Kimura, 1981; Tavaré, 1986; Posada \& Crandall, 1998).

Bootstrap analyses were performed under maximum likelihood algorithm using GARLI (Zwickl, 2006) and were set for 1000 bootstrap replicates. The majority-rule trees were then constructed in PAUP* v.4.0b10 (Swofford, 2000). Bootstrap (BS) values of $90 \%-100 \%$ were interpreted as strong support, $70 \%-89 \%$ as moderate, $50 \%-69 \%$ as weak, and those under $50 \%$ were not reported. We identify some clades as "group" in regular script when there is no formal genus name for them (e.g., "Miliaceae group"), or with the genus in italics when there was at least one species included with others that have not been formally transferred (e.g., "Eriocoma group").

Bayesian posterior probabilities were estimated using the program MrBayes v.3.01 (Huelsenbeck \& Ronquist, 2001; Ronquist \& al., 2005) with DNA substitution models selected using the program MrModeltest v.1.1b (Nylander, 2002). The plastid dataset was then partitioned into four subsets (1: trnkmatK + rps $3+r p s 16-t r n K+r p l 32-t r n L ; 2:$ mat $K+$ trnL-F + rps 16 intron; 3: trnH-psbA; 4: $n d h F$ ) and were processed implementing different parameters suggested by Akaike information criterion (Table 2). The ITS data were calculated separately. Each Bayesian analysis was initiated with random starting trees and initially run for two million generations, sampling once per 100 generations. The analysis was continued until the value of standard deviation of split sequences dropped below 0.01 as the convergence diagnostic value (Huelsenbeck \& Ronquist, 2001). The fraction of the sampled values discarded as burn-in was set at 0.25 .

The test of alternative phylogenetic hypotheses was accomplished using parametric bootstrapping (Huelsenbeck \& al., 1995; Swofford \& al., 1996; Goldman \& al., 2000) as implemented in Mesquite v.2.6 (Maddison \& Maddison, 2009). The best-scoring maximum likelihood tree (the optimal topology for unconstrained dataset) and simulation model parameters were obtained using GARLI (Zwickl, 2006) for the single GTR $+\mathrm{G}$ model of sequence evolution in maximum likelihood searches. The same procedure was repeated for the maximum likelihood searches with monophyly constraints consistent with the research or alternative hypothesis (other than the null hypothesis). The constraint topology and model parameters were used to simulate 1000 data matrices equal in size to the original matrix using Mesquite v.2.6. These parameters were then used in PAUP* to find the most parsimonious trees constructed under topological constraints and the most parsimonious unconstrained trees. Differences in tree length for constrained and unconstrained searches for each of the 1000 simulated matrices were calculated and plotted as histograms using Mesquite v.2.6. The distribution of tree length differences between two potential topologies was estimated. If the difference between constrained and unconstrained topologies fell outside the $95 \%$ confidence interval of this distribution $(P<0.05)$, the alternative hypothesis was rejected.

Scanning electron microscopy. - Lemma ultrastructure was studied using dry mature seeds sampled from herbarium specimens from the majority of the Stipeae species used in the phylogenetic analysis. To remove epicuticular wax the lemmas were cleaned in xylene for four hours. Samples were mounted and then covered with gold from a vacuum spray gun (JII-4X, Japan). The ultrastructure of the lemma was studied at varying magnifications using a Jeol (JSM35C, Japan) scanning electron microscope.

We illustrate the lemma epidermal pattern (LEP) for 44 species (Figs. 3-4); 32 of these have never been published; eight of these (Achnatherum hymenoides (Roem. \& Schult.) Barkworth, Achnatherum stillmanii (Bol.) Barkworth, Oryzopsis asperifolia Michx., Piptatheropsis canadensis (Poir.) Romasch. $\&$ al., Piptatheropsis micrantha (Trin. \& Rupr.) Romasch. \& al., Piptatherum miliaceum (L.) Coss., Ptilagrostis kingii (Bol.) Barkworth, Ptilagrostis mongolica (Turcz. ex Trin.) Griseb.) are of much higher quality and/or complement ink drawings; three of these (Celtica gigantea (Link) F.M. Vázquez, Macrochloa tenacissima (Loefl. ex L.) Kunth, Nassella neesiana (Trin. \& Rupr.) Barkworth) confirm previous work (Thomasson, 1978, 1980; Barkworth, 1983; Barkworth \& Everett, 1987; Vásquez \& Barkworth, 2004); and one replaces an erroneously published pattern for Stipa pennata L. (Vásquez \& Barkworth, 2004).

Cytogenetics. - We surveyed the original literature and floristic treatments for chromosome numbers reported for species of Stipeae, and discuss the possible evolution of base chromosome numbers in the tribe (see Appendix 3 in the Electronic Supplement for reported chromosome numbers).

\section{RESULTS}

Analysis of plastid sequences. - Since very little difference and no contradictions in generic composition or arrangement were observed among maximum likelihood trees in the individual plastid analyses, the data were combined.

The combined plastid data provides a rather well-resolved tree, mostly with high backbone support (Fig. 1). The first split on the phylogenetic tree strongly indicates $(\mathrm{BS}=99, \mathrm{PP}=1.00)$ the Phaenospermateae ( $\mathrm{BS}=89, \mathrm{PP}=1.00)$ to be sister to the remainder of the Pooideae represented by the tribes Meliceae, Poeae, Diarrheneae, and Stipeae $(\mathrm{BS}=99, \mathrm{PP}=1.00)$. There is strong support for clades of Meliceae-Brylkinieae $(\mathrm{BS}=99$, PP $=1.00)$, Diarrhenaeae-Poeae $(\mathrm{BS}=100, \mathrm{PP}=1.00)$, and Stipeae $(\mathrm{BS}=100, \mathrm{PP}=1.00)$. However, the relationships among these clades are weakly supported $(\mathrm{BS}=66, \mathrm{PP}=0.86$ ).

\footnotetext{
Fig. 1. Phylogram of maximum likelihood tree from analysis of plastid data. Numbers above branches are bootstrap values; numbers below branches are posterior probability values; taxon colour indicates native distribution; 13 indels, one stem loop hairpin formation, and lemma epidermal patterns (LEP) are mapped on the tree.
} 


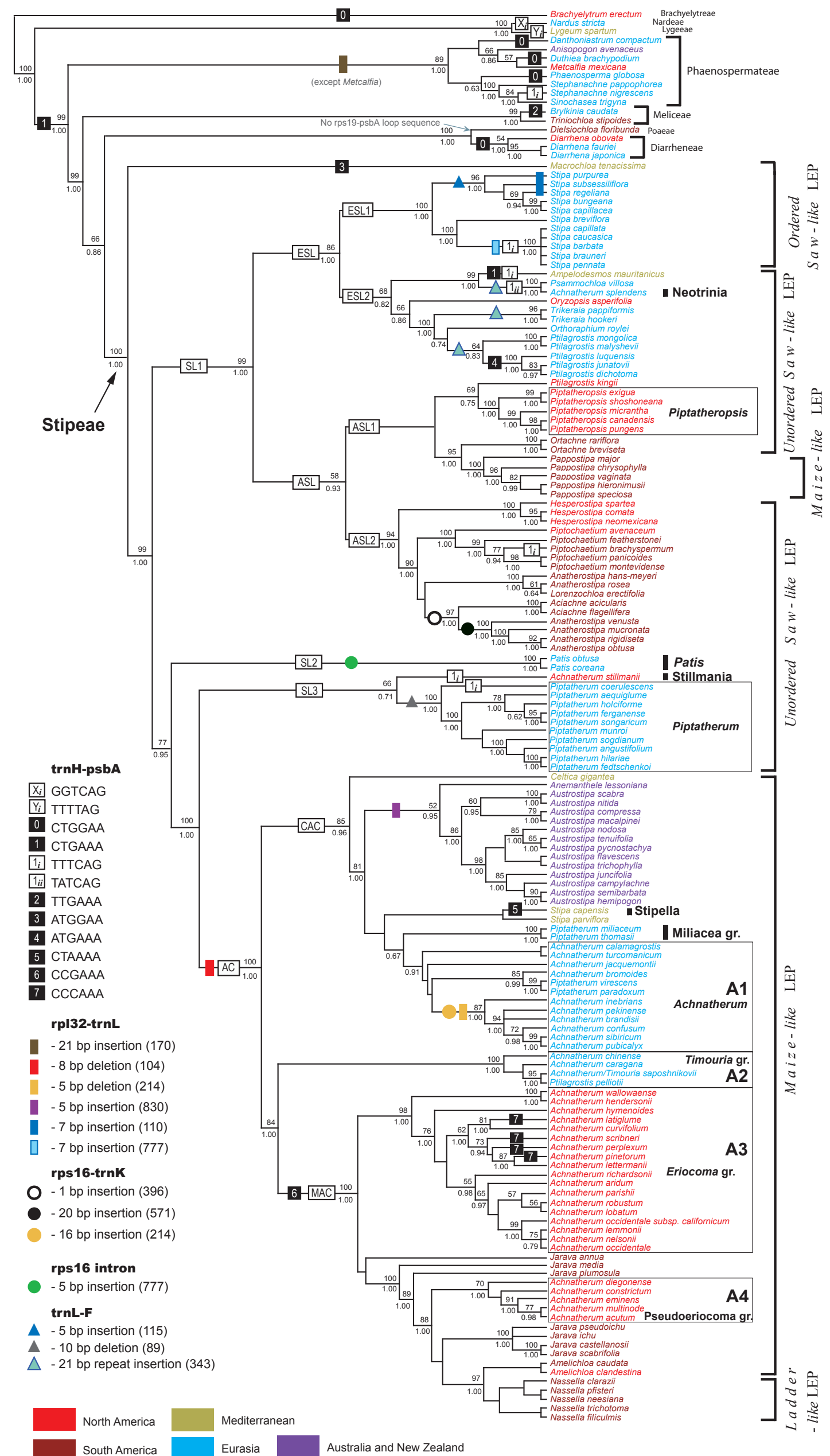


Within Stipeae, the monotypic genus Macrochloa is resolved as sister to a clade of all remaining taxa with strong support $(\mathrm{BS}=99, \mathrm{PP}=1.00)$. Above this split Stipeae comprise three well-supported clades, each with a saw-like LEP, and we refer to these clades as SL1, SL2, and SL3. A fourth lineage that is the sister of SL3 we designate as the "achnatheroid clade" (AC).

The first saw-like lineage (SL1; BS $=99, \mathrm{PP}=1.00$ ) consists of two geographically distinct clades: one is primarily distributed in Eurasia, which we call the "Eurasian saw-like lineage (ESL)," the other is distributed in the Americas, which we call the "American saw-like lineage (ASL)". The ESL (BS = 86, $\mathrm{PP}=1.00)$ consists of two clades: the Stipa s.str. clade (BS = $100, \mathrm{PP}=1.00$ ), which we refer to as the ESL1 that includes the type of Stipa (S. pennata). This clade is split into two strongly supported clades: (1) a clade that includes $S$. purpurea Griseb., S. subsessiliflora (Rupr.) Roshev., S. regeliana Hack., S. bungeana Trin., and $S$. capillacea Keng $(\mathrm{BS}=96, \mathrm{PP}=1.00)$ and (2) a clade that includes $S$. pennata, S. brauneri (Pacz.) Klokov, $S$. barbata Desf., S. caucasica Schmalh., S. capillata L., and $S$. breviflora Griseb. $(\mathrm{BS}=100 ; \mathrm{PP}=1.00)$. The other is a weakly supported, taxonomically complex clade $(\mathrm{BS}=68$, PP $=0.82$ ), which we refer to as the ESL2 clade that includes Ptilagrostis s.str. as well as several monotypic or ditypic genera such as Ampelodesmos, Psammochloa Hitchc., Achnatherum splendens (Trin.) Nevski ("Neotrinia", Romaschenko \& al., 2010), Oryzopsis asperifolia (the only American representative of this clade), Trikeraia, and Orthoraphium Nees. The ESL2 clade includes a strongly supported Ampelodesmos-Psammochloa"Neotrinia" clade (BS =99, $\mathrm{PP}=1.00)$ in which Ampelodesmos is sister to a clade of Psammochloa and "Neotrinia" (BS $=100$, $\mathrm{PP}=1.00)$. The other, weakly supported clade ( $\mathrm{BS}=66, \mathrm{PP}=$ 0.86) within ESL2 includes Oryzopsis asperifolia as sister to a strongly supported Trikeraia-Orthoraphium-Ptilagrostis clade $(\mathrm{BS}=100, \mathrm{PP}=1.00)$. A strongly supported clade $(\mathrm{BS}=96$, $\mathrm{PP}=1.00$ ) of Trikeraia species is part of a clade that includes Orthoraphium roylei Nees and five species of Ptilagrostis; their relationships are not well-resolved. The monophyly of Ptilagrostis s.str. (excluding P. kingii and P. pelliotii (Danguy) Grubov) is weakly supported ( $\mathrm{BS}=64, \mathrm{PP}=0.83$ ). However, two clades within Ptilagrostis are strongly supported (BS = $100, \mathrm{PP}=1.00$ ): one includes Ptilagrostis mongolica (the type) and $P$. malyshevii Tzvelev; and the other includes $P$. luquensis P.M. Peterson \& al., P. junatovii Grubov, and P. dichotoma Keng ex Tzvelev.

The ASL clade is weakly supported $(\mathrm{BS}=58, \mathrm{PP}=0.93)$, and comprises two clades: ASL1 and the ASL2. The ASL1 clade has no support and splits into two major clades: (1) a clade (BS $=69, \mathrm{PP}=0.75)$ that encompasses Ptilagrostis kingii as sister to the strongly supported Piptatheropsis clade (BS $=100, \mathrm{PP}=$ $1.00)$ that includes five former members of North American $P i$ ptatherum (called the "Piptatheropsis group" by Romaschenko $\&$ al., 2010; and 2011 - as a new genus); and (2) a South American clade $(\mathrm{BS}=95, \mathrm{PP}=1.00)$ that includes a monophyletic Ortachne and Pappostipa, each with strongly supported (BS = 100 and $\mathrm{PP}=1.00$ ) crown nodes. The ASL2 clade is strongly supported $(\mathrm{BS}=94, \mathrm{PP}=1.00)$ and includes a monophyletic
Hesperostipa $(\mathrm{BS}=100$ and $\mathrm{PP}=1.00)$ from North America as sister to a strongly supported clade $(\mathrm{BS}=90, \mathrm{PP}=1.00$ ) of the remaining species. Among these remaining species there is a single clade of the pan-American genus Piptochaetium (BS = $100, \mathrm{PP}=1.00$ ) as sister to a clade containing the South American genera Aciachne, Anatherostipa and Lorenzochloa Reeder $\&$ C. Reeder. Anatherostipa s.l. is polyphyletic, since two species, A. hans-meyeri (Pilg.) Peñailillo and A. rosea (Hitchc.) Peñailillo, are united in a clade with Lorenzochloa $(\mathrm{BS}=100$, $\mathrm{PP}=1.00)$ that is sister to a strongly supported $(\mathrm{BS}=100, \mathrm{PP}$ $=1.00$ ) clade that includes Aciachne plus the remaining Anatherostipa s.str. species $(\mathrm{BS}=97, \mathrm{PP}=1.00)$. The Aciachne clade, composed of two species, is strongly supported $(\mathrm{BS}=100$, PP $=1.00)$, and this is sister to the Anatherostipa s.str. clade (BS = $100, \mathrm{PP}=1.00$ ) composed of four species.

The sister to the SL1 clade, which includes all remaining species (clades SL2, SL3, and AC) is moderately supported (BS $=77, \mathrm{PP}=0.95)$. The $\mathrm{SL} 2$ clade $(\mathrm{BS}=100, \mathrm{PP}=1.00)$ contains the far East-Asian Patis which in this tree includes P. obtusa (Stapf) Romasch. \& al. (三 Piptatherum kuoi S.M. Phillips \& Z.L. Wu) and P. coreana (Honda) Ohwi (三 Achnatherum coreanum (Honda) Ohwi) and is sister to a strongly supported clade $(\mathrm{BS}=100, \mathrm{PP}=1.00)$ including SL3 and the AC. The SL3 clade $(\mathrm{BS}=66, \mathrm{PP}=0.71)$ encompasses the morphologically isolated North American species Achnatherum stillmanii ("Stillmania") as sister to a strongly supported clade of Eurasian Piptatherum s.str. ( $\mathrm{BS}=100, \mathrm{PP}=1.00$ ), including $P$. coerulescens (Desf.) P. Beauv., the type of this genus.

The strongly supported $\mathrm{AC}(\mathrm{BS}=100, \mathrm{PP}=1.00)$ contains three major clades. The "core achnatheroid clade" (CAC, BS = $85, \mathrm{PP}=0.96)$ is sister to a moderately supported clade ( $\mathrm{BS}=$ $84, \mathrm{PP}=1.00$ ) that is divided into two highly supported sister clades: the Asian "Timouria Roshev. group" (A2, PP =100, PP $=1.00)$; and the "major American clade" (MAC, BS $=100$, PP $=1.00$ ). $\mathrm{CAC}$ includes the monotypic western Mediterranean genus Celtica F.M. Vázquez \& Barkworth as sister to a moderately supported clade $(\mathrm{BS}=81, \mathrm{PP}=1.00)$ that consists of an Australian clade $(\mathrm{BS}=52, \mathrm{PP}=0.95)$ and a Eurasian clade of Achnatherum (A1, PP =0.91). The Australian clade includes Anemanthele, a monotypic genus from New Zealand, as sister to a monophyletic Austrostipa $(\mathrm{BS}=86, \mathrm{PP}=1.00$ ). The A1 clade encompasses 10 species of Achnatherum, including A. calamagrostis (L.) P. Beauv., the type of the genus, and two species of Piptatherum sect. Virescentia Roshev. ex Freitag (P. virescens (Trin.) Boiss. and P. paradoxum (L.) P. Beauv.). The two representatives of Piptatherum sect. Miliacea Roshev. ex Freitag (P. miliaceum (L.) Coss. and P. thomasii (Duby) Kunth) form a strongly supported clade ("Miliacea group," $\mathrm{BS}=100, \mathrm{PP}=1.00$ ) that is sister to the A1 clade. However, this sister relationship is poorly supported $(\mathrm{PP}=0.67)$. Thus, the Eurasian Piptatherum species are resolved in three distinct clades: Patis in SL2, Piptatherum s.str. in SL3, the "Miliacea group" and $P$. sect. Virescentia in CAC. North American species formerly treated in Piptatherum are contained in SL1 in the genus Piptatheropsis. Stipa capensis Thunb. and S. parviflora Desf. (of the monotypic Stipa sects. Stipella Tzvelev and Inaequeglumes (Bor) F.M. Vazquez \& Devesa) of arid 
Mediterranean origin are united without any support and appear as sister to the "Miliacea group" plus A1 clade.

The "Timouria group" (A2, BS $=100, \mathrm{PP}=1.00)$ consists of the central Asian species Timouria saposhnikovii Roshev., A. chinense, A. caragana (Trin.) Nevski, and Ptilagrostis pelliotii.

The MAC is strongly supported $(\mathrm{BS}=100, \mathrm{PP}=1.00)$ and is split into two separate clades: the "Eriocoma group" (A3, BS $=98, \mathrm{PP}=1.00)$, and a complex clade $(\mathrm{BS}=100, \mathrm{PP}=1.00)$ that includes the "Pseudoeriocoma group" (A4, BS =70, PP = 1.00) and representatives of Jarava, Nassella, and Amelichloa. The "Eriocoma group" and "Pseudoeriocoma group" include North American species currently placed in Achnatherum but they are resolved in separate, strongly supported clades. Species of Achnatherum within AC have maize-like LEPs and are scattered in four clades: two Eurasian (A1, A2) and two of North American origin (A3, A4). Achnatherum splendens ("Neotrinia") of the SL1/ESL2 clade, and A. stillmanii ("Stillmania") of the SL3 clade, have saw-like LEPs.

Jarava аппиа (Mez) Peñailillo is located in an unsupported grade between the "Eriocoma group" A3, and the other members of MAC. These other members of MAC form a strongly supported clade $(\mathrm{BS}=100, \mathrm{PP}=1.00)$ that includes a grade of $J$. media (Speg.) Peñailillo and J. plumosula (Nees ex Steud.) F. Rojas (members of former Stipa subg. Ptilostipa Speg.Spegazzini, 1901; Roig, 1964), the "Pseudoeriocoma group" A4), Jarava s.str., Amelichloa, and Nassella. Jarava plumosula is sister to a clade ( $\mathrm{BS}=89, \mathrm{PP}=1.00$ ) that includes an unresolved trichotomy of the "Pseudoeriocoma group" (A4, BS = $70, \mathrm{PP}=1.00)$, Jarava s.str. (BS $=100, \mathrm{PP}=1.00$, including the type, J. ichu Ruiz \& Pav.), and the Amelichloa-Nassella clade (BS = 97, $\mathrm{PP}=1.00$ ). The "Pseudoeriocoma group" (A4) is composed of five south-western North American species, primarily distributed in Mexico.

Plastid DNA minute inversions and indels. - Minute inversions were detected in rpl32-trnL and trnH-psbA. However, only in data from the $t r n H-p s b A$ region were we able to find cases of clear phylogenetic utility. We identified a stem-loop hairpin formation involving a small region flanking the inverted repeat $\left(\mathrm{IR}_{\mathrm{A}}\right.$-LSC). All taxa in our dataset (except Dielsiochloa, which lacks the loop) exhibited a hairpin formation characterized by relatively long and conserved stem sequences (averaging $19 \mathrm{bp}$ in length) linked by a short loop (6 bp). The poly-A end of $I R_{A}$ is sometimes partially involved in the stem formation. Polymorphic sequences in the trnH-psbA hairpin loop and inverted loop were mapped on our plastid tree. This loop proved to be inverted in some sequences (Fig. 1: $\mathrm{X}_{i}, \mathrm{Y}_{i}, 1_{i}$ and $1_{i i}$. The sequences from the loop also exhibited base mutations that accumulate in a phylogenetically informative order in some cases (Fig. 1: sequence 0 gives rise to 1 and frequently reverses except in Stipeae above Macrochloa; 1 independently gives rise to 2, and (within Stipeae) to 3, 4, 5, and 6; and 6 gives rise to 7). The change from state 1 to state 6 marks the MAC clade, and this is not reversed, but does give rise to state 7 in some Achnatherum A3 elements. In this loop sequence CTGGAA (type " 0 " in Fig. 1) is common among members of early diverging lineages of Pooideae (Brachyelytrum P. Beauv.,
Danthoniastrum, Duthiea, Phaenosperma) but is absent in Stipeae. This sequence is also characteristic of Diarrhena. Nardus L. and Lygeum Loefl. ex L. exhibit specific inversions $\mathrm{X}_{i}$ and $\mathrm{Y}_{i}$ of unknown sequence origin. For a more detailed discussion of the stem-loop hairpins see Appendix 2.

Thirteen indels were detected in four of our sequenced plastid regions: six in rpl32-trnL, three in rps16-trnK, one in rps16 intron, and three in $\operatorname{trn} L-F$. These are identified by their starting position within the aligned sequences and are mapped on the tree (Fig. 1). In rpl32-trnL a 21 bp insertion (170) was found in all representatives of the Phaenospermateae except Metcalfia. The 7 bp insertion (110) indicates a possible alternative relationship between plastids of three species of Stipa (S. purpurea, S. subsessiliflora, S. regeliana). Another 7 bp insertion (777) confirms the monophyly of four species in the ESL1 clade (this taxon set is also supported by minute inversion $1_{i}$ ). The 8 bp deletion (104) supports the monophyly of the entire AC clade. Within AC a 5 bp insertion (830) adds support for the entire Australia-New Zealand clade, and a $5 \mathrm{bp}$ deletion (214) supports a central and east Asian subclade of six species within Achnatherum A1: A. inebrians (Hance) Keng ex Tzvelev, A. pekinense (Hance) Ohwi, A. brandisii (Mez) Z.L. Wu, A. confusum (Litv.) Tzvelev, A. sibiricum (L.) Keng ex Tzvelev, and A. pubicalyx (Ohwi) Keng.

The rps16-trnK region exhibited two independent insertions in the ASL2 clade of different lengths. A $1 \mathrm{bp}$ insertion (396) marks Aciachne and Anatherostipa s.str. from the Anatherostipa hans-meyeri-A. rosea-Lorenzochloa clade. This is followed by a 20 bp insertion (571) marking the separation of the Anatherostipa s.str. from the Aciachne clade. The Asian Achnatherum A1 clade of six species, mentioned above, is additionally supported by a 16 bp insertion (214). In the rps16 intron a 5 bp insertion (777) is unique to the Patis clade.

A trnL-F 5 bp insertion (115) supports the monophyly of S. purpurea, S. subsessiliflora, S. regeliana, S. bungeana, and S. capillacea. A 10 bp deletion (89) marks the crown node for the Piptatherum s.str. clade. A 21 bp repeat insertion (343) is confined to ESL2 and appears three times in that clade. It was detected in Psammochloa-Achnatherum splendens ("Neotrinia") clade, Trikaraia clade, and the Ptilagrostis s.str. clade.

Analysis of ITS sequences. - The ITS phylogenetic tree is poorly resolved with little backbone support (Fig. 2). The bifurcation between Brachyelytrum, Nardus-Lygeum, and the rest of the Pooideae has weak support $(\mathrm{BS}=60, \mathrm{PP}=0.94)$. The Phaenospermateae tribe is not monophyletic as its elements are distributed among the first three branches after the Brachyelytrum and Nardus-Lygeum split. The only supported clade within Phaenospermateae $(\mathrm{BS}=100, \mathrm{PP}=1.00)$ contains two species of Stephanachne and Sinochasea. Triniochloa (Meliceae) and Dielsiochloa (Poeae) are united with minimal support.

The monophyly of Stipeae is poorly supported (only PP = 0.76). Most major clades identified in the plastid tree (Fig. 1) are not detected in the ITS tree (Fig. 2). Only SL3 with poor support ( $\mathrm{PP}=0.67)$, SL2 (analysis includes only Patis obtusa), AC (including Pappostipa s.str.) with strong support (BS = $94, \mathrm{PP}=1.00)$, and MAC with poor support $(\mathrm{PP}=0.62)$ are found in the ITS tree. Species found in the plastid ESL2 clade 
are placed into two remote clades in the ITS tree, one with a strongly supported Ptilagrostis s.str. $(\mathrm{BS}=96, \mathrm{PP}=100)$, and one with a moderately supported set of the other ESL2 members $(\mathrm{BS}=81, \mathrm{PP}=100)$ (excluding Othoraphium which aligns near Patis). Ampelodesmos is sister to a moderately supported Psammochloa-"Neotrinia"-Oryzopsis-Trikeraia clade (BS = 83 , PP $=1.00$ ). The phylogenetic relationships of Psammochloa and "Neotrinia" are strongly supported $(\mathrm{BS}=98, \mathrm{PP}=1.00)$. This clade is sister to the Oryzopsis-Trikeraia clade (BS $=57$, $\mathrm{PP}=0.67)$ wherein Oryzopsis is sister to the monophyletic Trikeraia $(\mathrm{BS}=99, \mathrm{PP}=1.00)$. In the ITS analysis, in contrast to the plastid analysis, Hesperostipa $(\mathrm{BS}=99, \mathrm{PP}=1.00)$ is sister to the AC-Pappostipa clade. Piptochaetium (BS $=83$, $\mathrm{PP}=1.00)$ and Ortachne s.str. $(\mathrm{BS}=90, \mathrm{PP}=1.00)$ are again well-resolved. The union of Piptatheropsis with Ptilagrostis kingii as sister appears as in the plastid tree, but with poor support ( $\mathrm{PP}=0.61)$. A clade of Aciachne and Anatherostipa s.l. is weakly supported $(\mathrm{BS}=68, \mathrm{PP}=1.00)$ here and not in the plastid tree. However, we lack ITS data for Lorenzochloa.

The AC clade is strongly supported $(\mathrm{BS}=94, \mathrm{PP}=100$ ). There is poor support for Celtica as sister to all the other members of $\mathrm{AC}(\mathrm{BS}=54, \mathrm{PP}=0.99)$. However, the plastid CAC clade is not resolved in the ITS tree, it collapses into a series of unsupported subclades and a large polytomy. Five notable relationships well-supported by ITS data and also resolved in the plastid CAC clade are: (1) a clade of two species of Old World Piptatherum of sect. Virescentia $(\mathrm{BS}=95, \mathrm{PP}=0.99$ ); (2) a clade of Piptatherum sect. Miliacea species (BS $=100$, PP = 1.00); (3) an Austrostipa-Anemanthele clade ( $\mathrm{PP}=0.94)$; (4) a strongly supported clade of some Eurasian Achnatherum A1 members ( $\mathrm{BS}=92, \mathrm{PP}=1.00)$ (however, other $\mathrm{A} 1$ elements, A. calamagrostis, A. turcomanicum Tzvelev, and A. jacquemontii (Jaub. \& Spach) P.C. Kuo \& S.L. Lu, are scattered in our trees); and (5) a strongly supported Pappostipa clade (BS $=91$, $\mathrm{PP}=1.00$ ).

The MAC clade appears intact in the ITS tree (except for the ejection of Jarava annua), but has poor support $(\mathrm{PP}=0.62)$. MAC includes four principal clades placed in a polytomy, and these are similar to the plastid clades: (1) "Eriocoma group" (A3, PP $=0.81$ ); (2) a strongly supported Jarava s.str. clade $(\mathrm{BS}=91, \mathrm{PP}=1.00)$; (3) a portion of the "Pseudoeriocoma group" is strongly supported and this includes Achnatherum acutum (Swallen) Valdes-Reyna \& Barkworth, A. eminens (Cav.) Barkworth, and A. multinode (Scribn. ex Beal) ValdesReyna \& Barkworth $(\mathrm{BS}=99, \mathrm{PP}=1.00)$, but this does not include A. constrictum (Hitchc.) Valdes-Reyna \& Barkworth or A. diegoense (Swallen) Barkworth; and (4) a weakly supported Amelichloa-Achnatherum diegoense-Nassella clade $(\mathrm{PP}=0.64)$. This latter clade includes a weakly supported clade of five species of Nassella $(\mathrm{BS}=68, \mathrm{PP}=0.98$ ) as sister to the weakly supported clade of two species of Amelichloa (strongly supported, $\mathrm{BS}=99, \mathrm{PP}=1.00$ ) with Achnatherum diegonense $(\mathrm{BS}=65, \mathrm{PP}=0.87)$.
Testing alternative phylogenetic hypotheses. - There are four clades that have markedly different relationships based on the plastid (p, Fig. 1), and nuclear (n, Fig. 2) datasets: (1) Hesperostipa, (2) Pappostipa, (3) Ptilagrostis s.str., and (4) Piptatherum s.str-Achnatherum stillmanii. We examined the robustness of each of these clades under the constrained alternative topologies.

(1) In the plastid tree (p) Hesperostipa is placed within ASL2 as sister to the Piptochaetium-Anatherostipa-Lorenzochloa-Aciachne clade (hypothesis A); based on ITS (n), Hesperostipa is sister to the Pappostipa-AC clade (hypothesis B). The heuristic search using the plastid dataset under the constraints (to be part of, or sister to, the AC clade as in ITS) indicates that 21 extra steps (constituting $0.83 \%$ of the entire tree length) were needed for Hesperostipa to be resolved as sister to AC. The analysis of distribution of tree length differences in Mesquite v.2.6 revealed that only eight extra steps would be needed if the hypothesis of a sister-group relationship between Hesperostipa and AC were true. Therefore, hypothesis B was rejected at $P<0.05$, and it was concluded that Hesperostipa and Pappostipa-AC could not form a clade based on the plastid data. Hypothesis A was tested in the nuclear dataset and the difference between unconstrained and constrained most parsimonious trees resulted in 10 extra steps for the nuclear dataset $(0.74 \%)$. The analysis of the distribution of tree length differences yielded an equal to higher number of extra steps allowed at $P<0.05$ as likely outcome if hypothesis A were true. Therefore, hypothesis A, namely that Hesperostipa belongs to ASL (Fig. 1), is accepted.

(2) Pappostipa was resolved as member of ASL (p) and was placed as nested within $\mathrm{AC}(\mathrm{n})$. The two hypotheses required $16(\mathrm{p} ; 0.63 \%)$ and 31 (n; 2.05\%) extra steps. The analysis of the distribution of tree length differences was expected to be observed more than $0.05 \%$ of the time. Thus both hypotheses were rejected.

(3) Ptilagrostis s.str. was resolved as member of ESL2 (p) and was placed as sister to a clade of Patis, Ortachne, Piptatheropsis, Piptochaetium, Anatherostipa, and Aciachne (n). The two hypotheses required 13 (p; 0.51\%) and $22(\mathrm{n} ; 1.47 \%)$ extra steps. The analysis of the distribution of tree length differences was expected to be observed more than $0.05 \%$ of the time. Thus, both hypotheses were rejected.

(4) Piptatherum s.str--Achnatherum stillmanii was resolved as sister to $\mathrm{AC}(\mathrm{p})$ and was placed as sister to the remaining Stipeae excluding Macrochloa (n). The two hypotheses required nine (p; $0.36 \%)$ and $23(n ; 1.5 \%)$ extra steps. The analysis of the distribution of tree length differences was expected to be observed more than $0.05 \%$ of the time. Thus, both hypotheses were rejected for all datasets.

Lemma micromorphology. - Lemma epidermal pattern (LEP) is diagnosed by several characters: length and shape of the walls of the fundamental cells (FC), length and shape of silica cells (SC), presence or absence of silica bodies (SB),

Fig. 2. Phylogram of maximum likelihood tree from analysis of nuclear ITS data. Numbers above branches are bootstrap values; numbers below branches are posterior probability values; taxon colour indicates native distribution; lemma epidermal patterns (LEP) are mapped on the tree. 


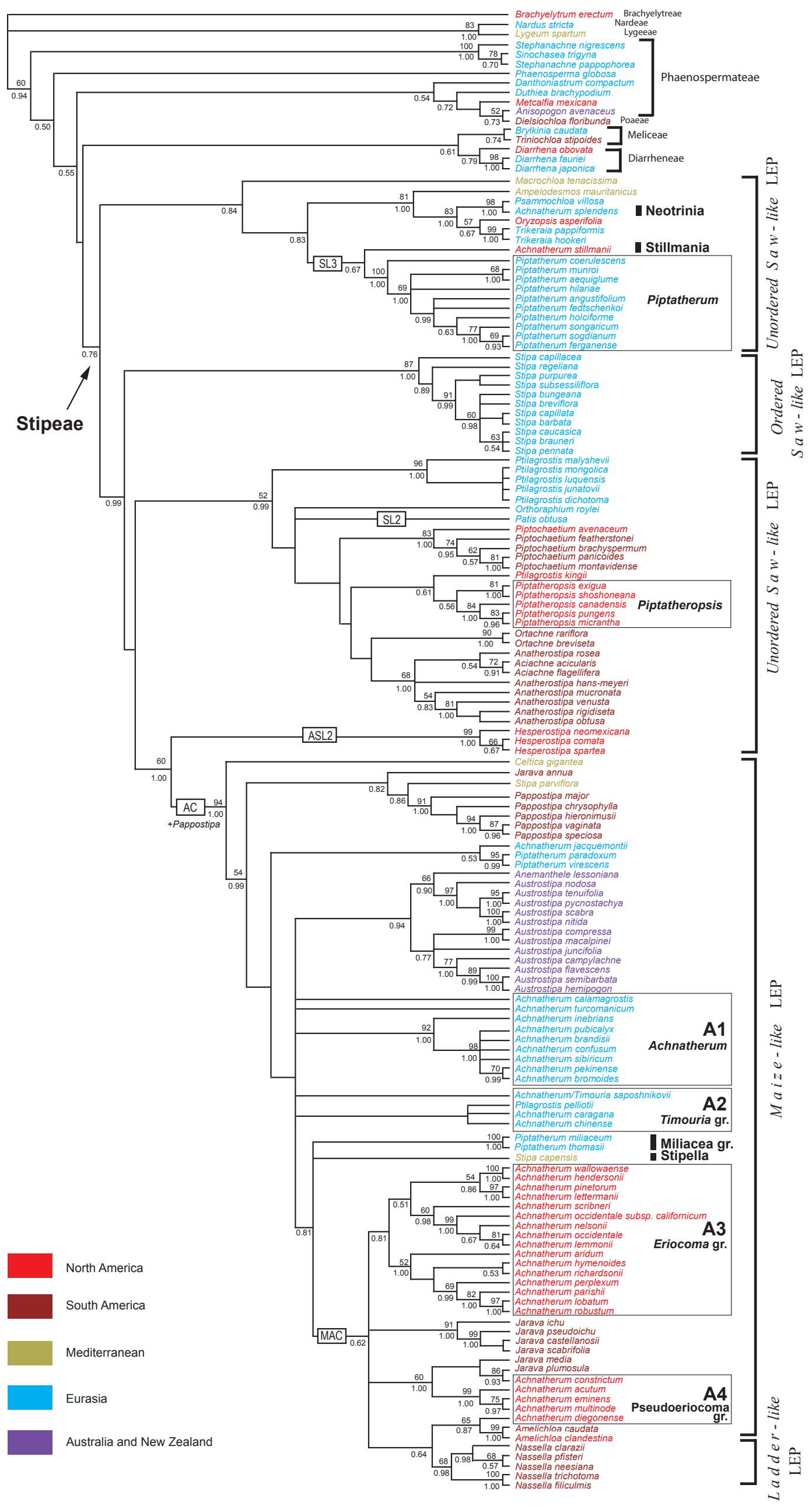


presence, absence, or frequency of cork cells (CC), presence or absence of prickles (hooks), shape of the prickle base, etc. (Thomasson, 1978; Ellis, 1979; Romaschenko \& al., 2008, 2010).

- Saw-like LEP (SLP) pattern is common in Stipeae and widespread among grasses outside of this tribe (Fig. 3A-Y; Finot \& al., 2006; Liu \& al., 2010; Peterson, 1989; Romaschenko \& al., 2008; Thomasson, 1986; Valdes-Reyna \& Hatch, 1991). Features of this type are the presence of elongate (usually very long, i.e., more than $2 \times$ longer than wide) $\mathrm{FC}$ with sinuate to lobate sidewalls (Romaschenko \& al., 2008). The FC alternate with SC containing SB. Cork cells are usually paired with SC and situated adjacent to the proximal end-wall of the SC/SB pairs of cells. Within Stipeae we distinguished six major subtypes of SLP.

1. Macrochloa SLP (Fig. 3B, E-J, V, Y) as a non-CC variant has $\mathrm{FC}$ of variable length that are 3-7 times longer than $\mathrm{SC}$ that contain $\mathrm{SB}$, and often alternate with $\mathrm{SB}-\mathrm{CC}$ pairs. The silica bodies in these species are round or slightly elongated and the CC are square to crescent-shaped. Prickles (with rounded prickle base) and unicellular microhairs are usually present and the sidewalls are thick, dentate (Macrochloa, Oryzopsis, Patis obtusa, Piptatherum: Fig. 3B, H, V, Y) or lobate (Ampelodesmos, Psammochloa, "Neotrinia", Trikeraia: Fig. 3E-G, I, J). In Trikeraia the lemma surface appears striate at less than $10 \times$ magnification. This striate pattern is homogeneous within the Ampelodesmos-Psammochloa-"Neotrinia"-Trikeraia group with the exception of Trikeraia hookeri (Stapf) Bor (Fig. 3J) which has slightly elongated SB (not rounded as in others) and often has a shallow contraction near the middle. Cork cells were not observed in Patis obtusa (Fig. 3V).

2. Stipa SLP (Fig. 3C, D) is characteristic of the ESL1 clade which encompasses the members of Stipa s.str. The FC are square to twice as long as wide, of nearly uniform shape and alternate with SC in a regular (ordered) pattern. All other SLP subtypes do not have consistent pairing of SC with FC (unordered). The SC are ornamented with square-based prickles and sometimes have adjacent dorsally compressed CC. The sidewalls of the FC are thick and deeply sinuous.

3. Ptilagrostis SLP (Fig. 3K-N, U, W as non-CC variant) has $\mathrm{FC}$ that are of variable length and are 2-7 times longer than SC, and often alternate with SC-CC pairs. Silica bodies vary in length and are rectangular with straight walls or with 2-5 shallow contractions. The CC are square. The sidewalls of the FC are sinuous, not thickened. Prickles and unicellular microhairs are often present. These characteristics are found in
Ptilagrostis s.str., Ptilagrostis kingii, and Piptatheropsis (Fig. 3L-N). The CC are less abundant within ASL1 than in Ptilagrostis s.str. Within the Ptilagrostis SLP we recognize three variations: Orthoraphium roylei (Fig. 3K) with extremely long and irregularly placed SB with multiple (up to five) shallow contractions, "Stillmania" LEP that resembles Orthoraphium with the sidewalls of the SB almost straight and without constrictions (CC not observed), and Patis coreana (Fig. 3U) with elongated silica bodies often with single deep constriction at the mid-point (CC not observed).

4. Hesperostipa SLP (Fig. 3T) has FC that are long, with deeply sinuous and thick sidewalls. Prickles and unicellular microhairs are present, and CC and SB were not observed.

5. Aciachne SLP (Fig. 3O, Q-S; including Ortachne, Peñailillo, 2005) has FC that are long with lobate, thick sidewalls and rounded silica bodies sometimes with shallow contractions that are 2-6 times shorter than the FC, and $\mathrm{CC}$ that are rightangled to crescent-shaped. Small prickles are sparse. Apart from Aciachne (Fig. 3S) we also recognize variations of this subtype in Anatherostipa mucronata (Griseb.) F. Rojas (Fig. 3R), A. rosea (Fig. 3Q), and Lorenzochloa (Fig. 3O). The LEP of $A$. mucronata differs in having SB of irregular shape, slightly elongate with 1-2 shallow to deep contractions, and CC were not observed in $A$. mucronata.

6. Anatherostipa SLP (Fig. 3P) is found in the remaining species of Anatherostipa s.str. It is distinguished by lemma surfaces densely covered with prickles on the SC. It includes elongated FC with lobate, thick walls, producing a striate appearance on the surface that is also densely covered with prickles above the SC. The SB are irregularly shaped and rare, and $\mathrm{CC}$ were not observed.

- Maize-like LEP (MLP) is confined to Stipeae. Within Stipeae this LEP is specific to achnatheroid grasses and, with the exception of Pappostipa, is restricted to the AC clade. Species with this pattern have thin-walled FC that are approximately equal in length and width to significantly shorter than wide (with few exceptions) with mostly straight sidewalls. The FC are oval, round, square-round, or longitudinally compressed, and all have often square-cornered or sometimes round SB that regularly alternate with FC. In the typical syndrome, where SB are densely packed and regularly alternate with compressed $\mathrm{FC}$, the lemma surface resembles the surface of a fruiting inflorescence ("ear") of corn (maize). SC-CC pairs are scarce to absent. We distinguished four MLP subtypes, two of which occur in a single species.

Fig. 3. Saw-like lemma epidermal pattern (LEP) found in all lineages of Stipeae with exception of Achnatheroid clade and Pappostipa. A, Stephanachne nigrescens [Miehe 94-547-9, Miehe \& Wündisch (Marburg University)]. B, Macrochloa tenacissima [Pyke 701 (BC)]. C, Stipa subsessiliflora [Ivanov s.n. (LE)]. D, Stipa pennata [Romaschenko 466 (BC)]. E, Ampelodesmos mauritanicus [Pyke 702 (BC)]. F, Psammochloa villosa [Safronova 952 (LE)]. G, Achnatherum splendens [Soreng 5121, Peterson, Wang \& Zhu (US)]. H, Oryzopsis asperifolia [Saarela 384 (UBC)]. I, Trikeraia pappiformis [Soreng 5653, Peterson \& Sun(US)]. J, Trikeraia hookeri [Koelz 2328 (US)]. K, Orthoraphium roylei [Soreng 5261, Peterson \& Sun (US)]. L, Ptilagrostis mongholica [Koloskov s.n. (LE)]. M, Ptilagrostis kingii [Peirson 10819 (US)]. N, Piptatheropsis micrantha [Peterson 18437, Saarela \& Smith (US)]. 0, Lorenzochloa erectifolia [Peterson 14074 \& Tovar (US)]. P, Anatherostipa rigidiseta [Becks.n. (LPB)]. Q, Anatherostipa rosea [Laegaard 10864 (AAU)]. R, Anatherostipa mucronata [Peterson 19551, Soreng, Salariato \& Panizza (US)]. S, Aciachne acicularis [Peterson 13931 \& Refulio Rodriguez (US)]. T, Hesperostipa spartea [Holmes 214 (US)]. U, Patis coreana [Liou 1085 (US)]. V, Patis obtusa [Soreng 4531 \& Kelley (US)]. W, Achnatherum stillmanii [Hoover 4614 (US)]. Y, Piptatherum ferganense [Kamelin $100(\mathrm{LE})] . c c=$ cork cell; $f c=$ fundamental cell; $m h=$ macrohair; $s b=$ silica body. 

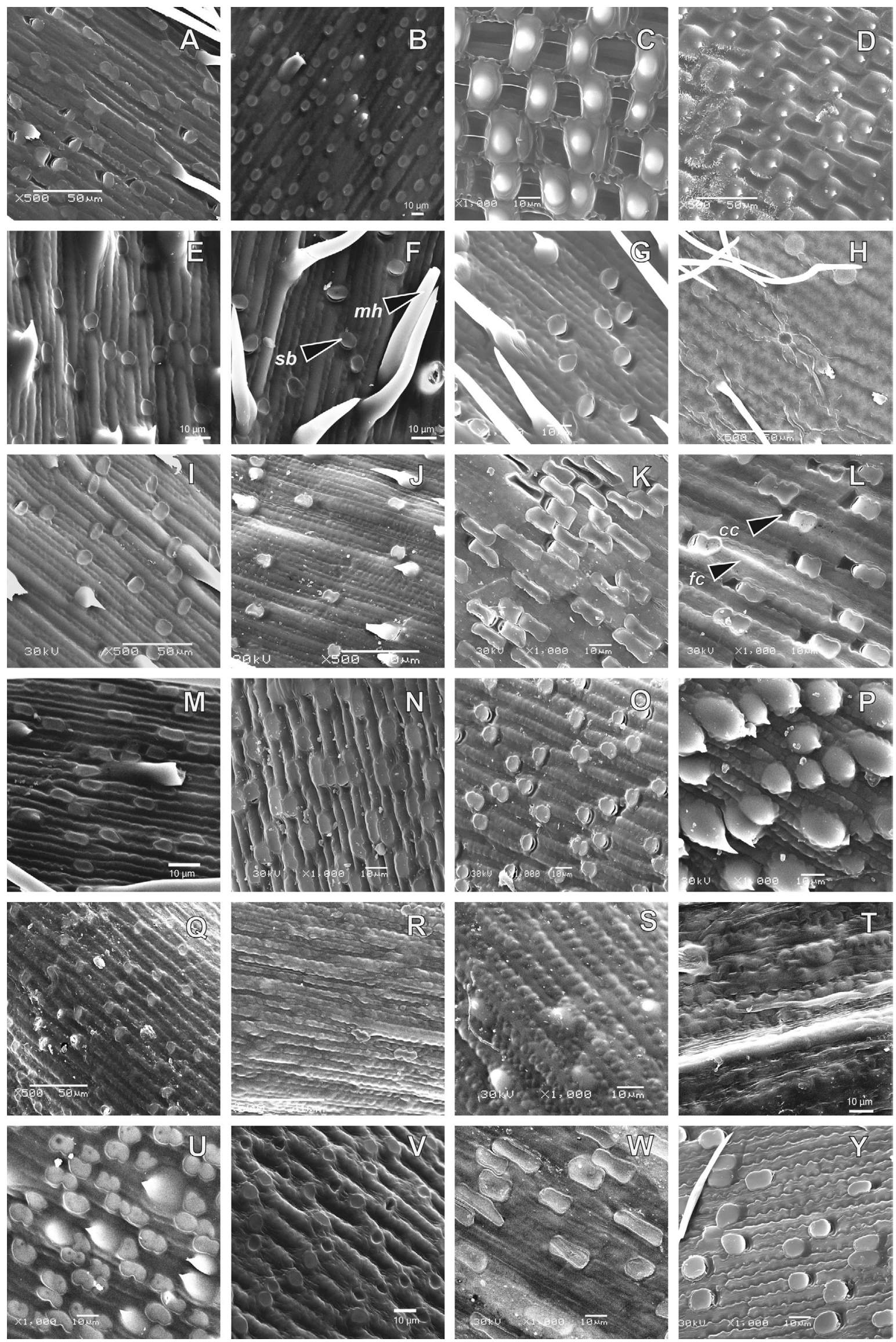

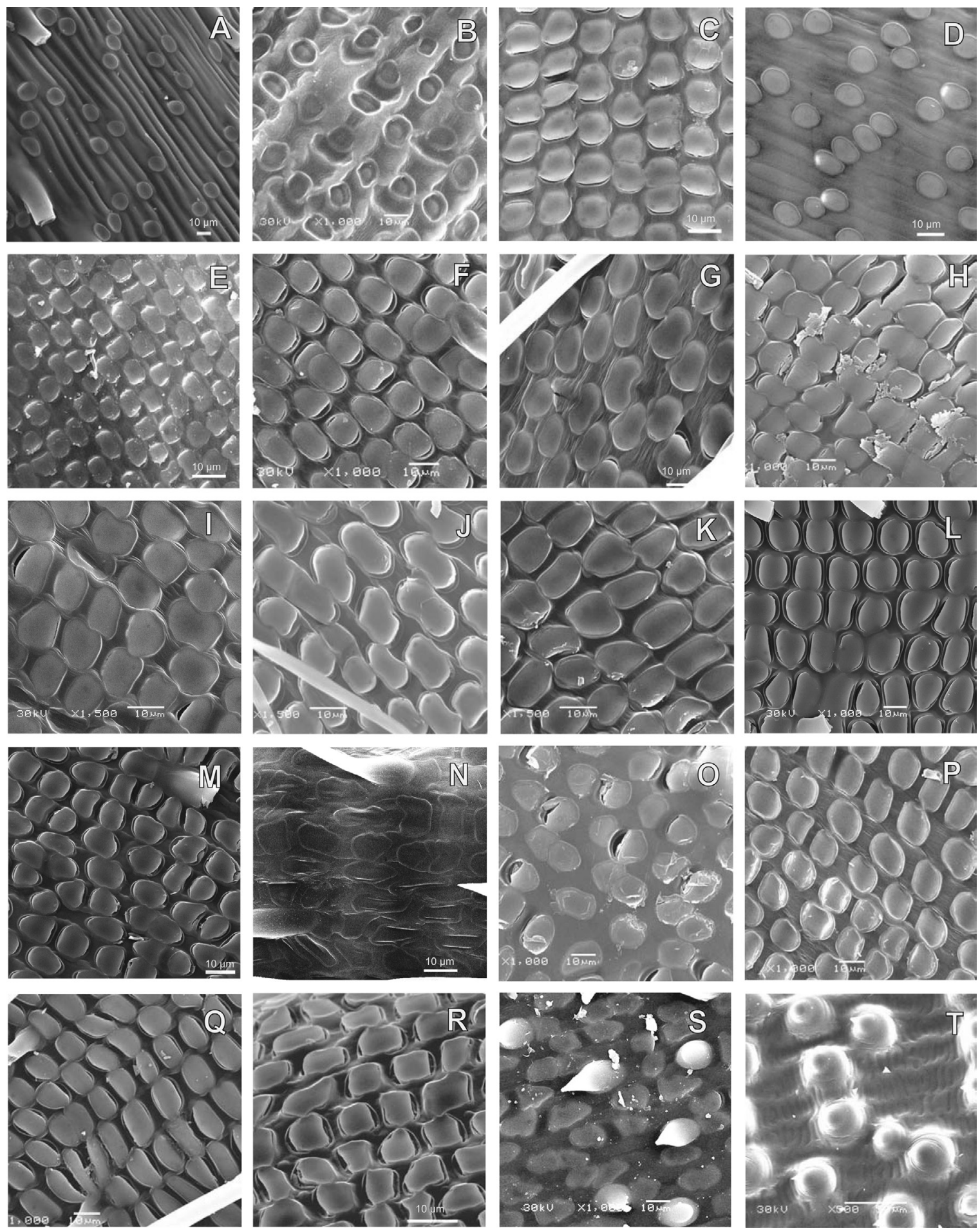

Fig. 4. Maize-like and ladder-like lemma epidermal patterns (LEP) characteristic of Achnatheroid grasses. A, Celtica gigantea [Pyke 705 (BC)]. B, Stipa capensis [Pyke 703 (US)]. C, Stipa parviflora [Romaschenko 74 \& Romo (US)]. D, Piptatherum miliaceum [Gillet 16094 (US)]. E, Anemanthele lessoniana [Mez 13236 (US)]. F, Austrostipa scabra [Peterson 14442, Soreng \& Rosenberg (US)]. G, Achnatherum pubicalyx [Kozlov 124 (LE)]. H, Achnatherum turcomanicum [Goncharov 162 \& Grigoriev (LE)]. I, Piptatherum virescens [Romaschenko 445 \& Didukh (KW)]. J, Timouria saposhnikovii [Soreng 5475, Peterson \& Sun (US)]. K, Achnatherum caragana [Goloskokov s.n. (US)]. L, Achnatherum chinense [Petrov s.n. (LE)]. M, Ptilagrostis pelliotii [Grubov 1815 (LE)]. N, Jarava annua [Peterson 15614 \& Soreng (US)]. 0, Achnatherum hymenoides [Saarela $205(\mathrm{UBC})]$. P, Achnatherum occidentale [Saarela 594, Sears \& Maze (UBC)]. Q, Achnatherum eminens [Peterson 10952 \& Annable (US)]. R, Jarava ichu [Peterson 20745, Soreng \& Romaschenko (US)]. S, Amelichloa clandestina [Barkworth 5103 (US)]. T. Nassella neesiana [Peterson 10258 \& Annable (US)]. 
1. Celtica MLP (Fig. 4A) is one of the two exceptions within the MLP that have very long FC (5-10 times longer than SC) with thick sidewalls. However, the sidewalls of the FC are straight as is the common condition in the MLP. The SB are round and CC were not observed. This pattern is somewhat transitional between SLP and MLP.

2. Miliacea MLP (Fig. 4D) is a thin-walled version of the Celtica MLP. The FC are 3-5 times longer than SB, and have straight sidewalls. The SB are round, very rarely associated with $\mathrm{CC}$, and the $\mathrm{CC}$ are crescent-shaped.

3. Stipella MLP (Fig. 4B) is found only in "Stipella" (Stipa capensis). This pattern has large $\mathrm{CC}$ that are wider than $\mathrm{SB}$ in the adjacent SC. Additionally, the sidewalls of FC are thick and slightly sinuous. The CC are usually regularly associated with $\mathrm{SB}$, which is unusual for achnatheroids (see also $S$. parviflora note below in MLP subtype 4).

4. Achnatherum MLP (Fig. 4C, E-S) is widespread among achnatheroids, and is found in Pappostipa (Romaschenko \& al., 2008). Species in Achnatherum s.str., Austrostipa, Anemanthele, "Timouria group", "Eriocoma group", "Pseudoeriocoma group", Jarava, and Amelichloa have this pattern where the CC are scarce but are prevalent in the "Eriocoma group". The length of the SB varies within each group. A pattern of equally narrow (longitudinally compressed) FC and SB was found in the "Pseudoeriocoma group". Jarava annua (Fig. $4 \mathrm{~N}$ ) and Amelichloa (Fig. 4S) share an unusual version of this MLP subtype by having irregularly shaped SB and variable length FC. Stipa parviflora (S. sect. Inaequiglumes (Bor) F.M. Vazquez \& Devesa) shares a typical MLP and lacks prominent $\mathrm{CC}$ and thick FC sidewalls but is distinct from the Stipella MLP (described above for Stipa capensis).

- Ladder-like LEP (Fig. 4T) is thought to be unique to Stipeae and restricted to Nassella. This pattern includes longitudinally compressed FC and SC that are frequently of similar size. The SB do not fill the lumen of the SC, thus the FC and $\mathrm{SC}$ are sometimes indistinguishable. Both types of cells are thin-walled and aligned in regular alternate rows. Cork cells were not observed.

\section{DISCUSSION}

Phylogenetic relationships of early diverging lineages in Pooideae. - The position of tribe Brachyelytreae as sister to Nardeae plus Lygeeae and the rest of the subfamily Pooideae is confirmed by numerous phylogenetic analyses (Davis \& Soreng, 1993, 2007, 2010; Clark \& al., 1995; Catalán \& al., 1997; Barker \& al., 1999; Hilu \& al., 1999; Hsiao \& al., 1999; Soreng \& Davis, 2000; GPWG, 2001; Mathews \& al., 2002; Döring \& al., 2007; Soreng \& al., 2007; Bouchenak-Khelladi \& al., 2008; Schneider \& al., 2009). Our analysis based on the nine plastid regions confirms the position of Phaenospermateae after the separation of Nardeae-Lygeeae, as sister to the remaining Pooideae. These are followed by Meliceae as sister to Diarrheneae-core Pooideae-Stipeae. This scenario does not contradict the maximum parsimony strict consensus topology of Davis \& Soreng (2010). All these tribes, and nodes supporting tribe arrangement, are strongly supported, except for the order of Meliceae as sister to Stipeae plus DiarrheneaePoeae. The latter pair has low BS support in our trees.

In our analyses Phaenospermateae s.l. have moderate support, and Phaenosperma is nested among Duthieinae genera. Monophyly of Phaenospermateae is also supported by the presence of a unique $21 \mathrm{bp}$ insertion in rpl32-trnL, which is absent only in Metcalfia. Since Phaenospermateae are excluded from the Meliceae-core Pooideae-Diarrheneae-Stipeae clade with strong support, placement of Phaenospermateae and/or Duthieinae within a broadly defined Stipeae is rejected.

Lineages and reticulation within Stipeae. - Relationships within Stipeae have been debated and analyzed over the last 50 years (Freitag, 1975, 1985; Tzvelev, 1976; Clayton \& Renvoize, 1986; Barkworth \& Everett, 1987; Arriaga \& Barkworth, 2006; Barkworth, 2007; Jacobs \& al., 2007; Barkworth \& al., 2008; Romaschenko \& al., 2008, 2010, 2011). Although the general consensus, prior to Romaschenko \& al. (2008, 2010), was that achnatheroid-type morphology, with medium-sized spikelets with blunt calluses and unspecialized awns, gave rise to all other more specialized types of spikelet morphology, our DNA data strongly refute this. Taxa with achnatheroid-type spikelet morphology do not form a monophyletic group, but those with achnatheroid LEP do, and genera with achnatheroid spikelet morphology and SLP are mostly derived from genera with a different set of features such as those found in Macrochloa.

Macrochloa is strongly supported as sister to the remaining Stipeae. It has many peculiar features, such as long, bifid prophylls; unique leaf anatomy; short, truncate, velutinous ligules; protruding lemma lobes (Vázquez \& Barkworth, 2004), along with an unordered SLP (common among Phaenospermateae elements and in our SL clades).

We have found it useful to divide Stipeae into three groups: (1) Macrochloa with multiple autapomorphic features; (2) clades with SLP, which we refer to as SL lineages; and (3) those with MLP or ladder-like LEP, which we call achnatheroid grasses. The lemma epidermal patterns in the Macrochloa and SL lineages are mutually exclusive to the pattern found in achnatheroid grasses. Even though the achnatheroid grasses are monophyletic, it is clear that they are derived at some level from an ancestor with SLP.

The SL lineages, as they appear in the plastid tree (Fig. 1), do not form a monophyletic group. They resolve in three clades that diverge in a stepwise order; SL1, SL2, and SL3, with SL3 sister to the AC. Even though SL3 is weakly supported, an identical monophyletic group of SL3 taxa is found in both plastid and ITS trees, with identical internal branching order at the base. Although SL1 is strongly supported as the sister group to the set of SL2, SL3, and AC, there is only moderate support for the sister-group relationship of SL2 to SL3/AC. This significant weakness in the phylogenetic structure among SL lineages is reiterated by the different, although unsupported, relationships detected in the ITS analysis (Fig. 2). In the ITS tree SL2 and SL3 are resolved within two successive diverging clades of a non-monophyletic SL1, while Hesperostipa and Pappostipa are removed from the SL1/ASL1 clade in the plastid tree and placed as sister clades within AC in the ITS tree. 
The achnatheroid clade, which includes only taxa with maize-like or ladder-like LEP, is monophyletic (strongly supported, see Fig. 1), and is comprised of three subclades: (1) an Austral-Eurasian CAC with some isolated African elements, (2) an east Asian "Timouria group", and (3) an exclusively New World MAC. The stepwise order of SL2 and SL3, as sister to $\mathrm{AC}$, and CAC as sister to "Timouria group" plus MAC, are moderately to strongly supported and geographically consistent with a Eurasian origin of AC in the plastid tree. This geographical arrangement is contradicted by the ITS tree, which suggests an American origin of AC from the ancestors of Hesperostipa and Pappostipa. However, comparison of the distribution of tree length differences between the plastid and ITS trees (see results) lead us to favor the plastid hypothesis of Hesperostipa belonging within SL1 ASL clade.

The SLP clade including an ESL and an ASL lineage was detected in our previous study based on five plastid regions (see clades 1 and 2 in Romaschenko \& al., 2010). With addition of four more plastid regions the SL1 clade is now strongly supported (Fig. 1). The combination of the Eurasian and American SLs in one clade is not consistent with the topology obtained from ITS. Despite alternative hypotheses generated from different datasets, only inferences based on the plastid analysis had strong bootstrap support. We conclude that the incongruence between the ITS and plastid tree is perhaps due to stochastic processes and/or independent reticulation events in the ITS evolution during the origin of Stipa, Ptilagrostis, Orthoraphium, and Pappostipa, although we have not tested for this (Humphreys \& al., 2010). Within ESL Stipa s.str. is strongly supported, but in a narrower sense than previously understood by taxonomists. We detected two strongly supported clades, which provide the first insight into infrageneric structure of Stipa based on molecular data. One clade includes S. capillacea, S. bungeana (both of S. sect. Leiostipa Dumort.), and three taxa of disputed placement. These latter three, Stipa purpurea (S. sect. Barbatae Junge), S. subsessiliflora (S. sect. Pseudoptilagrostis Tzvelev), and S. regeliana (S. sect. Regelia Tzvelev), are sometimes referred to different sections of Stipa, or included in Ptilagrostis (Roshevits, 1934; Tzvelev, 1974, 1977; Freitag, 1985). The monophyly of these three taxa is supported by a $7 \mathrm{bp}$ insertion in rpl32-trnL. The strongly supported clade of the above five species (Fig. 1) is marked by a $5 \mathrm{bp}$ insertion in the $t r n L-F$ region (unknown for $S$. capillacea and $S$. regeliana due to lack of $\operatorname{trnL}-F$ sequences). Stipa purpurea, $S$. subsessiliflora, and $S$. regeliana typically possess purplish glumes, relatively short awns, and short glumes with entire apices. Based on these characters Roshevits (1934) placed S. purpurea and S. subsessiliflora in Ptilagrostis. Based on morphological characters that resemble Ptilagrostis, Tzvelev (1976, 1977) and Freitag (1985) placed Stipa subsessiliflora in S. sect. Pseudoptilagrostis Tzvelev. In a detailed study of anatomical and gross morphological features of Ptilagrostis, S. subsessiliflora was thought to be closer to Ptilagrostis than to Stipa s.str. (Barkworth, 1983). Additionally, a numerical analysis (Barkworth, 1983) placed S. subsessiliflora between representatives of Ptilagrostis and Achnatherum (A. calamagrostis, A. caragana). The seemingly transitional nature of morphological features between Stipa and Ptilagrostis for S. purpurea, S. regeliana, and S. subsessiliflora, and some additional Achnatherum-like features for S. subsessiliflora, suggests reticulate or homoplasious origins. Widely divergent sequences of ITS (i.e., clones) have been found and these are the subject of a forthcoming paper (Romaschenko \& al., in prep.). The LEP of S. subsessiliflora is clearly of the saw-like type (Fig. 3C), in agreement with the placement of this species in Stipa. Even though the above three species of Stipa are resolved in a grade, their sequences differ very little. Since they share the same 7 bp insertion in rpl32-trnL (Fig. 1), evidence of common origin is supported. A second Stipa s.str. clade, supported by plastid and ITS analyses, comprises $S$. breviflora as sister to the strongly supported plastid subclade of five very closely related species that share a $7 \mathrm{bp}$ insertion in the rpl32-trnL region and an inversion type " 1 " in the trnH-psbA region (Fig. 1). These five species have been placed in four sections of Stipa according to Tzvelev (1976): sects. Leiostipa (S. capillata), Smirnovia Tzvelev (S. caucasica), Barbatae (S. barbata, S. brauneri), and Stipa (S. pennata). Within Stipa s.str. it appears that $S$. bungeana shares ITS characteristics with these five species and shares a plastid type with $S$. capillacea, indicating possible additional rounds of reticulation within the genus.

The Ampelodesmos-Psammochloa-"Neotrinia"-OryzopsisTrikeraia set (a grade in ESL2, see Fig. 1) all have SLPs, and, with one exception, are characterized by stout Eurasian species, usually more than one meter tall that occur in a diverse array of open habitats (Mediterranean scrub, Mongolian sand-dunes, arid steppe, and open mountain slopes of the Tibet-Qinghai plateau). The single species of Oryzopsis s.str. is exceptional as it is of moderate stature (Barkworth, 2007) and endemic to North American shady cool temperate forests. Except for Trikeraia with three species, the other genera are monotypic. All the genera have unusual characteristics. Ampelodesmos, Psammochloa, and Trikeraia are rhizomatous (an uncommon character in Stipeae) while "Neotrinia" (Achnatherum splendens) forms massive tussocks. All members of this group, along with $\mathrm{Mac}$ rochloa and Celtica, have well-developed lemma lobes flanking the central awn (lobes setiform in Ampelodesmos and Trikeraia), and such lobes are consistently small or absent elsewhere in the tribe. Achnatherum splendens was placed in Achnatherum sect. Neotrinia Tzvelev (Tzvelev, 1976). However, molecular data (Romaschenko \& al., 2010; Figs. 1-2 of this paper), and SLP (Fig. 3G) strongly advocate its position among Eurasian SLP lineages. Achnatherum splendens seems most closely related to Psammochloa villosa (Trin.) Bor based on molecular data.

Ampelodesmos has the most unusual spikelet features in Stipeae with multiple florets per spikelet and a prolonged rachilla above the uppermost floret (Stipeae otherwise have one floret and no rachilla extension, not even a rudiment of one), slender terminal untwisted undifferentiated awns (Stipeae awns are often twisted at the base), hairy ovaries (otherwise known only in Orthoraphium and Patis), and three lanceolate lodicules (2 or 3 in Stipeae) that are dorsally and marginally ciliate (Stipeae lodicules are glabrous except in Psammochloa) and strongly vascularized (Stipeae lodicules are usually faintly vascularized, except in Psammochloa). However, 
unlike other phylogenetically isolated Mediterranean taxa (e.g., Macrochloa, Celtica, and Stipa capensis), Ampelodesmos has a strongly supported sister relationship with the Asian pair of Psammochloa-"Neotrinia". Additionally, these three species share an inverted loop sequence in the trnH-psbA region of the chloroplast genome. It is most parsimonious to assume that the plastid sequence of Psammochloa-"Neotrinia" originated by $\mathrm{T} \rightarrow \mathrm{A}$ mutation in the already inverted " $l_{i}$ " sequence found in the Ampelodesmos plastid, rather than by a separate inversion and two mutations, or by five base changes from uninverted sequences. Soreng \& Davis (2000) suggested Ampelodesmos could be an ancient hybrid between Stipeae and an unknown ancestor, but that remains unproven.

The shared geography of the ASL(Fig. 1) lends additional support to the possible common origin of all the American taxa with SLPs, except Oryzopsis. However, the crown node is weakly supported and it splits into three clades: (1) Piptatheropsis plus Ptilagrostis kingii, (2) Ortachne-Pappostipa, and (3) Hesperostipa-Piptochaetium-Anatherostipa-AciachneLorenzochloa. There is no support for the joining of clades 1 and 2 (above) as sisters in ASL1 (Fig. 1) but ASL2 has strong support. The following is a detailed discussion of each of these clades.

(1) The North American genus Piptatheropsis, as previously depicted in Romaschenko \& al. $(2010,2011)$, is only distantly related to the Asian Piptatherum (Fig. 1). The sister to Piptatheropsis is Ptilagrostis kingii (weakly supported in the plastid tree), a North American species with transitional features between Piptatheropsis and Ptilagrostis (Barkworth, 1983), but we have no evidence that it is directly related to Asian Ptilagrostis s.str. The only other North American species of Ptilagrostis, P. porteri (Rydb.) W.A. Weber (not included in the present study) has a more complicated history and will be the subject of a forthcoming paper. Piptatheropsis-Ptilagrostis kingii are characterized by having the longest stem in the hairpin formation in the trnH-psbA region among Stipeae. This provides some evidence for independent evolution of this group.

(2) The Ortachne-Pappostipa sister relationship was strongly supported in the plastid analysis (Fig. 1). However, this relationship is difficult to reconcile since these species have little in common in their habits, chromosome numbers, and LEPs. Pappostipa species have MLP (Romaschenko \& al., 2008) while Ortachne has an unordered SLP (Peñailillo, 2005) similar to that of Piptatheropsis (Fig. 3N), Ptilagrostis kingii (Fig. 3M), Aciachne (Fig. 3S) and some species of Anatherostipa (Fig. 3Q-R). The Pappostipa clade was nested within, or sister to the AC in the ITS tree (Fig. 2). The probabilities of alternative placement of Pappostipa within ASL in the ITS tree was statistically insignificant. The LEP type being incompatible with that of other ASL genera and alternative phylogenetic placements in plastid and ITS trees indicates that Pappostipa arose from an ancient allopolyploid hybridization event.

(3) Some shared features of the Hesperostipa-Piptochaetium-Anatherostipa-Aciachne-Lorenzochloa clade have been reported in Hesperostipa, Anatherostipa, Piptochaetium, and the Miocene fossil genus Berriochloa (Thomasson, 1978; Barkworth \& Everett, 1987; Peñailillo, 2005). These include paleas with projecting keel apices and similarities in their unordered SLP. The Hesperostipa-Piptochaetium-Anatherostipa-Aciachne-Lorenzochloa clade was previously detected in phylogenetic studies (Cialdella \& al., 2010; Romaschenko \& al., 2010), but had not received strong support until now (Fig. 1). Results of our ITS tree place Hesperostipa outside ASL at the base of AC. However, the test of statistical significance of the differences in length between constrained and unconstrained trees showed a high probability that Hesperostipa should be included in ASL. The existing incongruence possibly reflects the high level of homoplasy in our ITS data. As a result, we postulate the correct phylogenetic position for Hesperostipa is (seen in Fig. 1) within ASL2 as sister to Piptochaetium, Anatherostipa, Aciachne, and Lorenzochloa. The lemma morphology of Hesperostipa corresponds well to what was found in Berriochloa. The LEPs of H. comata (Trin. \& Rupr.) Barkworth, H. neomexicana (Thurb.) Barkworth (Thomasson, 1978), and H. spartea (Trin.) Barkworth (Fig. 3T) look similar to those found in Berriochloa minuta Elias and B. maxima Elias (Thomasson, 1978). Thomasson (1978) described the lineage of Berriochloa-Hesperostipa-Piptochaetium as having LEPs with fundamental cells (FC) with deeply sinuous sides and end-walls, lacking silica bodies (SB) and cork cells (CC), and he estimated the time of separation of Hesperostipa and Piptochaetium to be late Pliocene. According to our data the SB/ CC pairs are common in SLP lineages (Fig. 3B, E-J, L, Y), outside of Stipeae (Fig. 3A), and are normally present in the Piptatheropsis-Ptilagrostis kingii clade (Fig. 3M-N). This suggests that the Berriochloa-Hesperostipa-Piptochaetium lineage (where short cells are absent) is a derivative of an ancestral extinct LEP where both types of short cells (silica and cork) evolved, and from which Piptatheropsis, Ptilagrostis kingii, and Ortachne are scarcely modified. Another piece of evidence is that the sister to Piptochaetium is the AnatherostipaAciachne-Lorenzochloa clade, where scarce SB were found in Anatherostipa mucronata and SB/CC pairs are present in Aciachne (Fig. 3R-S), representing stages of this loss.

A "pappose" subset of Anatherostipa species (A. rosea, A. hans-meyeri) is characterized by the presence of long hairs at the apex of the lemma, abundant SBs (Fig. 3Q), and a LEP that resembles Lorenzochloa and Ortachne. Our plastid tree clearly separates the A. rosea-A. hans-meyeri-Lorenzochloa clade from the remaining Anatherostipa s.str., which aligned with Aciachne in a strongly supported subclade (Fig. 1). The latter subclade is marked by single bp insertion in rps16-trnK, while the internal clade of remaining Anatherostipa s.str. is marked by a 20 bp insertion in the same region (Fig. 1). Such evidence reveals that Anatherostipa, as currently understood (Peñailillo, 1996), is polyphyletic. All plastid analyses, even when we excluded Pappostipa as putative conflicting taxon (results not shown), resolve Ortachne s.str. as an isolated lineage with no support for sister relationships between it and other ASL clades (other than Pappostipa).

Ptilagrostis and Patis are placed as potential sisters to the main body of ASL in the ITS analyses. A character that Ptilagrostis shares with ASL is a chromosome base number of $x=11$, but this is common among American SLP species (Barkworth, 1983). 
The SLP lineage 2 (SL2), i.e., Patis, is a newly detected strongly supported clade that includes two far East Asian, stout (to $1 \mathrm{~m}$ tall), broad- and flat-leaved species, Patis coreana and P. obtusa. The distribution of Patis coreana and P. obtusa overlap in the mesic temperate forests of eastern China (area of Hubei, Shaanxi, and Zhejiang provinces; Ohwi, 1941, 1942; Wu \& Philips, 2006), and occurs outside the ecological ranges of all but one other Asian Stipeae species, Achnatherum pekinense (including $A$. extremorientale (H. Hara) Keng). Patis coreana and $P$. obtusa share a 5 bp insertion in the rps 16 intron (Fig. 1) and these two species were recognized as being anomalous within their former respective genera (Wu \& Phillips, 2006). Patis coreana was originally described in Stipa and has been placed in Achnatherum and Orthoraphium by Ohwi (1941, 1953). These two species of Patis apparently represent a distinct and isolated lineage since they do not align in our phylogenetic analysis with Stipa, Orthoraphium, Piptatherum, or Achnatherum (Romaschenko \& al., 2011). The LEP of $\mathrm{Pa}$ tis coreana is clearly of the saw-like type (Fig. 3U), whereas Patis obtusa, differs in having rounded SB resembling those of Piptatherum s.str. (Fig. 3Y) except that the SB/CC pairs are scarce, and side-walls of the FC are thicker. A third species, Patis racemosa (Sm.) Romasch. \& al. from North America, has been transferred into the genus (Romaschenko \& al., 2011). Patis coreana and P. obtusa have prominent transverse veinlets between the longitudinal veins of the glumes (these are visible but faint in P. racemosa), and all three species have wide, long flag-leaf blades and underdeveloped or absent basal leaf-blades (i.e., they have cataphylls).

The SLP lineage 3 (SL3) or Piptatherum-"Stillmania" is weakly supported in the plastid tree (Fig. 1) and the ITS tree (Fig. 2). In each tree "Stillmania" is sister to a strongly supported Piptatherum (2). The phylogenetic position of SL3 is contradictory among the three analyses. In the plastid analysis it is rendered as sister to the AC and in the ITS tree it is placed as sister to Ampelodesmos-Psammochloa-Oryzopsis-Trikeraia. The LEP of "Stillmania" (Fig. 3W) is of the saw-like type and resembles that of Ptilagrostis (Fig. 3L; Barkworth, 1983) and Piptatherum (Fig. 3Y), but differs by having SBs of irregular length and alternation, and the lack of associated cork cells (CC). The provisional name "Stillmania" is used to represent Achnatherum stillmanii from the western part of North America. It was once placed in Ptilagrostis by Elias (1942), although Barkworth (1983) provided morphological and numerical evidence for placing it in Achnatherum. It shares some morphological features with Achnatherum, but differs by not having a MLP, possessing notched paleas with extended keels, and prominent lemma lobes.

The Piptatherum s.str. clade received strong support in all phylogenetic analyses (Figs. 1-2) (Romaschenko \& al., 2010). Members of this clade share a $10 \mathrm{bp}$ deletion in the $\operatorname{trn} L-F$ region. Morphological characters supporting the Piptatherum s.str. clade are dorsally compressed spikelets, linear disarticulation scars, and basally unfused and well-separated lemma margins (Romaschenko \& al., 2010). This combination of characteristics is consistent throughout this clade and do not appear in Piptatheropsis, Patis, or the "Miliacea group". Historically, other morphological features used to broadly circumscribe Piptatherum (Roshevitz, 1951; Freitag, 1975; Tzvelev, 1976; Dorn, 2001; Soreng, \& al., 2003; Wu \& Phillips, 2006; Barkworth, $\&$ al., 2008), such as small anthoecia, dark, often glossy and coriaceous lemmas, and well-exposed paleas, are found in $\mathrm{Pa}$ tis, Piptatheropsis, and various Eurasian taxa including species of Piptatherum sect. Miliacea (P. miliaceum, P. thomasii) and sect. Virescentia ( $P$. virescens, $P$. paradoxum). These features all appear to result from convergence (Romaschenko \& al., 2010, 2011).

The AC is strongly supported in the phylogenetic analyses (Figs. 1-2) and is marked by a unique 8 bp deletion in the rpl32trnL region. This terminal clade differs from Macrochloa and the SLP clades by having a distinct MLP with shortened FC with straight to slightly sinuate side-walls.

The CAC was detected in previous studies (Romaschenko $\&$ al., 2008, 2010) but without statistical support. In the current analysis it received moderate bootstrap support in the plastid tree (Fig. 1). Within CAC the monotypic Mediterranean genus Celtica (Vázquez \& Barkworth, 2004) is sister to the remainder, which includes clades of: Stipa capensis and S. parviflora, Anemanthele and Austrostipa, Eurasian "Miliacea group" (Piptatherum miliaceum, P. thomasii), and Eurasian Achnatherum (A1). The LEP of Celtica is unusual among achnatheroids because it has long FC (Fig. 4A). However, the side-walls of the FC are straight which is in agreement with the LEP concept described for achnatheroid grasses, but it may represent the transitional form between saw-like and maizelike LEPs. Assuming $x=12$ is the base chromosome number, Celtica is an octoploid $(2 n=96)$, which is the highest known ploidy level in Stipeae (also found in Ampelodesmos).

Two other Mediterranean taxa, Stipa capensis and S. parviflora, were placed at the base of Achnatherum (A1) plus the "Miliacea group", but without support in the plastid analysis (Fig. 1). Tzvelev (1976) placed S. capensis in a monotypic Stipa sect. Stipella and Freitag (1985) added S. parviflora to the section based on these two taxa having an unusually short palea. Vázquez \& Devesa (1996) accepted the placement of S. capensis, but placed S. parviflora in another monotypic Stipa sect. Inaequiglumes. Our phylogenetic and LEP evidence indicates that both taxa should be removed from Stipa and treated as members of the AC clade. The LEPs of S. capensis and S. parviflora are different; S. parviflora is typical maize-like (Fig. 4C) and $S$. capensis is unique among achnatheroids because it has enlarged cork cells often associated with silica cells/bodies (Fig. 4B). The ITS tree did not resolve these taxa as a pair and there was only low support for their phylogenetic isolation. Thus, the phylogenetic placements of $S$. capensis $(2 n=18,26,34,36)$ and $S$. parviflora $(2 n=28)$ remain somewhat ambiguous.

The "Miliacea group" consists of two closely related species (Piptatherum miliaceum, P. thomasii) that were placed in Piptatherum (Roshevits, 1951; Freitag, 1975; Tzvelev, 1976) after the application of the name Oryzopsis to non-North American taxa was discontinued (Romaschenko \& al., 2011). This group shares a chromosome number of $2 n=24$ with the Piptatherum s.str. clade and Achnatherum (A1). However, the set of morphological characters outlined for Piptatherum s.str. in this study is 
not consistent with that of the "Miliacea group". The lemmas of $P$. miliaceum and $P$. thomasii are not coriaceous, the disarticulation scars are circular (transversally elliptic in Piptatheropsis), and the lemma borders are basally fused (pers. obs.). The LEP of the"Miliacea group" represents a third unique type in the achnatheroid clade (Fig. 4D), which together with phylogenetic evidence and other morphological differences support the isolation of this group from Piptatherum and Achnatherum.

Achnatherum as broadly circumscribed (our A1 to A4, "Neotrinia", and "Stillmania") includes 35 North American species, about 20 species from Eurasia, and one from New Zealand. Following Tzvelev (1976), the species currently accepted by the Flora of China in Achnatherum (Wu \& Philips, 2006) are attributable to five general groups with the following characteristics: (1) callus short, often obtuse; awn straight or flexuous, articulated; lemma membranous with apical lobes (Achnatherum sect. Achnatherum; Stipa sect. Lasiagrostis Steud., type: A. calamagrostis - Freitag, 1985; Vázquez \& Devesa, 1996); (2) callus short, often obtuse; awn straight; lemma at maturity becoming dark and coriaceous, with apical lobes, only marginally covering the palea (Achnatherum sect. Aristella (Trin.) Tzvelev, type: A. bromoides (L.) P. Beauv.-Tzvelev, 1976; Stipa [unranked] Aristella Trin.; Stipa sect. Aristella (Trin.) Steud.-Freitag, 1985; Vázquez \& Devesa, 1996); (3) callus conspicuous, often acute; awn once or twice geniculate; lemma at maturity becoming dark and coriaceous, with absent or inconspicuous lobes, and completely covering the palea (Achnatherum sect. Achnatheropsis (Tzvelev) Prob., type: A. sibiricum-Freitag, 1985; Stipa sect. Achnatheropsis Tzvelev-Freitag, 1985; Tzvelev, 1976; Achnatherum sect. Protostipa Tzvel.; Stipa ser. Sibiricae Roshev.-Bor, 1970); (4) callus short, obtuse; awn straight, caducous; lemma pilose, membranous, covering the palea by $2 / 3$, with apical lobes; palea minutely protruding above the lemma apex (Achnatherum sect. Neotrinia, type: A. splendens - Tzvelev, 1976); and (5) callus short, obtuse; awn straight, caducous; lemma pilose, membranous, covering most of the palea, with apical lobes; palea shorter than lemma (Timouria, type: T. saposhnikowii-Roshevitz, 1916].

Our molecular study provides strong evidence for Achnatherum sect. Achnatheropsis being a natural group. It includes Achnatherum sibiricum, A. confusum, A. pekinense, and A. brandisii (Roshevits, 1934; Bor, 1970; Tzvelev, 1976, 1977; Freitag, 1985), along with A. pubicalyx and A. inebrians that have somewhat transitional features between this section and A. sect. Aristella. The Achnatherum-A1 clade (including the type of Achnatherum) received strong support in the ITS tree and little support in the plastid tree ( $\mathrm{PP}=0.91$ ) (Figs. 1-2). The crown node within this group is marked by two plastid indels, a 16 bp insertion in rps16-trnK and a 5 bp deletion in rpl32-trnL (Fig. 1). The other members of Achnatherum s.l. resolved as groups outside of $\mathrm{CAC}$, within $\mathrm{A} 2, \mathrm{~A} 3$, and $\mathrm{A} 4$ ("Eriocoma", "Pseudoeriocoma", and "Timouria groups") or as isolated species in SL1 and SL3 ("Neotrinia" and "Stillmania" lineages). More sampling in Achnatherum is needed to determine whether species with membranous lemmas (Achnatherum sect. Achnatherum) and species with coriaceous lemmas (sect. Aristella) represent natural groups.
Our current analysis confirms the position of Piptatherum virescens and P. paradoxum (Piptatherum sect. Virescentia) in CAC (Romaschenko \& al., 2010). These taxa share the same LEP as the majority of the other members of AC (Fig. 4I) and align with A. bromoides (sect. Aristella) in the plastid analysis with moderate support or without support in the ITS tree. The sister relationship of $A$. bromoides and $P$. sect. Virescentia is more plausible since the taxa share dark and coriaceous lemmas with a blunt callus, persistent awns, and similar habitats. Achnatherum bromoides, P. paradoxum, and $P$. virescens have a somewhat specialized lemma form that resembles that found in Piptatherum s.str., Piptatheropsis, and the "Miliacea group". The evident polyphyly of Achnatherum s.l. and Piptatherum s.l. reinforces the suggestion of Thomasson (1980: 235) that "similarities among taxa in the shape of the anthoecia are not in themselves sufficient to interpret phylogenetic relationships in Stipeae".

The monophyly of the Austrostipa-Anemanthele group is weakly supported in the plastid and ITS trees (Figs. 1-2). The

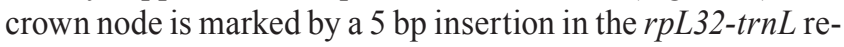
gion. In the ITS tree Anemanthele is embedded within Austrostipa, consistent with results of Jacobs \& al. (2000). However, in our plastid tree Anemanthele is sister to Austrostipa with weak support. The subgeneric structure within Austrostipa is poorly represented in the study. Of the several recovered clades only two represent separate subgenera: Austrostipa subg. Longiaristatae S.W.L. Jacobs \& J. Everett (1996; A. compressa (R. Br.) S.W.L. Jacobs \& J. Everett and A. macalpinei (Reader) S.W.L. Jacobs \& J. Everett), and Austrostipa subg. Austrostipa (A. campilachne (Nees) S.W.L. Jacobs \& J. Everett, A. semibarbata (R. Br.) S.W.L. Jacobs \& J. Everett, and A. hemipogon (Benth.) S.W.L. Jacobs \& J. Everett). The most densely sampled subgenus, Austrostipa subg. Falcatae S.W.L. Jacobs \& J. Everett (1996; A. scabra (Lindl.) S.W.L. Jacobs \& J. Everett, A. nitida (Summerh. \& C.E. Hubb.) S.W.L. Jacobs \& J. Everett, A. nodosa (S.T. Blake) S.W.L. Jacobs \& J. Everett, A. tenuifolia (Steud.) S.W.L. Jacobs \& J. Everett, and $A$. trichophylla (Benth.) S.W.L. Jacobs \& J. Everett), was polyphyletic in all our analyses. Based on our phylogenetic trees and the peculiar morphological types found in Austrostipa-Anemanthele, this strictly Australasian group presumably shares a common ancestor with Asian achnatheroids, both sharing the MLP (Fig. $4 \mathrm{E}-\mathrm{I})$ and general growth habit.

The "Timouria group" (A2) received strong support in our plastid tree (Romaschenko \& al., 2010). It encompasses Timouria, which was first described as a monotypic genus (Roshevits, 1916) and then included in a monotypic section of Achnatherum (as A. saposhnikovii; Tzvelev, 1976). In our plastid tree the "Timouria group" included Achnatherum caragana and A. chinense, which were aligned by Tzvelev (1976) and Freitag (1985), respectively, in Achnatherum sect. Neotrinia and Stipa sect. Lasiagrostis, and also Ptilagrostis pelliotii. Despite differences in gross morphology among its members they all share rather small (3-4 mm long), elliptic, 2-toothed, pubescent lemmas with caducous awns, 3 -veined glumes, and setaceous leaf blades. The LEP in the "Timouria group" is maize-like, often with extremely short fundamental cells (Fig. 4G-M). Molecular evidence and LEP place Ptilagrostis pelliotii within 
AC, far removed from the SL1 Ptilagrostis clade. The welldeveloped awn indumentum in P. pelliotii, approaching that of "true" Ptilagrostis, could be a result of convergent evolution.

Despite morphological similarities to members of Achnatherum (A1), the "Timouria group" represents an independent branch of Asian achnatheroid grasses with caducous awns and compressed, elliptic florets, whereas other Asian achnatheroids have persistent awns and terete, fusiform florets. The unusual characteristics of the "Timouria group" led Roshevits (1951) to describe subtribe Timouriinae to join smallest-spikeleted Asian and American genera, including Eriocoma (based on E. hymenoides (Roem. \& Schult.) Rydb.), Piptatherum, Oryzopsis, as well as Piptochaetium and Nassella in a narrow sense (Parodi, 1944, 1947). According to our plastid tree the "Timouria group" shares a common ancestor with MAC, which includes some of the largest genera in American Stipeae, such as the "Eriocoma group" (Achnatherum-A3), Jarava, and Nassella, with 29, 37, and 115 species, respectively.

The MAC was detected in previous phylogenetic analyses (Romaschenko \& al., 2008, 2010, 2011), and received strong support in our plastid tree. The monophyly of MAC is also supported by base mutation " 6 " in the loop sequence in $\operatorname{trnH}-p s b A$ region. The first split within MAC separates: (1) "Eriocoma group" (Achnatherum-A3) which includes the majority of North American Achnatherum species, from (2) an assemblage of Jarava, "Pseudoeriocoma group" (Achnatherum-A4), Nassella, and Amelichloa. Ignoring Jarava annua for the moment, these can be considered sister groups and are strongly supported in our plastid tree.

In the "Eriocoma group" (A3) A. wallowaense J. Maze \& K.A. Robson, A. hendersonii (Vasey) Barkworth, and A. hymenoides have short, elliptic, slightly laterally compressed florets, and lemmas with caducous awns (a Timouria-like character according to Roshevits, 1951). These three taxa form a grade leading to other "Eriocoma group" taxa that have terete and fusiform florets and lemmas with persistent awns (Fig. 1). The overall morphological pattern of fusiform florets in the "Eriocoma group" is similar to that in some species in the Asian Achnatherum (A1) clade, especially to those taxa in A. sect. Achnatheropsis that have a crown of hairs at the distal end of the lemma surrounding the base of the awn. This similarity lead Barkworth (1993) to transfer American species formerly placed in Stipa (Hitchcock, 1925a, b) to Achnatherum.

Another group of five species within MAC (Achnatherum diegonense, A. constrictum, A. eminens, A. multinode, A. acutum) appears to have a separate evolutionary history, and is called the "Pseudoeriocoma group" (A4). In both trees the "Pseudoeriocoma group" aligns in a subclade with Jarava and Nassella rather than with the "Eriocoma group" (Figs. 1-2). This grouping was detected by Barkworth \& al. (2008) based on a dataset which included ITS and plastid data. In our study this group is moderately supported in our plastid tree (Fig. 1), but in our ITS tree (Fig. 2) A. constrictum is aligned in a grade with Jarava, and A. diegonense is sister to Amelichloa caudata-A. clandestina. These results could be attributed to homoplasy within the ITS tree, or to past hybridization events. Since not all of the species of American Achnatherum were employed in our current study, the number of species allied to the "Pseudoeriocoma group" is uncertain. In the ITS tree (Fig. 2) a smaller strongly supported "Pseudoeriocoma group" of A. acutum, A. eminens, and A. multinode was sister to Jarava plumosula-J. media-A. constrictum; these two Jarava species were formerly placed in Stipa subg. Ptilostipa (Spegazzini, 1901; Roig, 1964). Jarava as broadly applied is obviously polyphyletic in our analyses, but separation of plumose and long-awned sect. Ptilostipa from other Jarava s.str. is consistent with our previous analyses (Romaschenko \& al., 2008, 2010) where larger sets of Jarava and Nassella taxa were included. The separation of Jarava plumosula and J. media (Stipa sect. Ptilostipa) from the "Pseudoeriocoma group" is consistent with the taxonomic distribution of relatively long (not less than half the length of the lemma) and hairy paleas, with two well-developed veins, a characteristic that these groups share with the "Eriocoma group". In contrast, in Jarava s.str. and Nassella the paleas are relatively short, glabrous or scarcely hairy, and the veins are faint or absent. The origin of the ladderlike LEP in Nassella is apparently derived from MLP ancestors which is found in species of Jarava, the "Timouria group" (A2), the "Eriocoma group" (A3), and the "Pseudoeriocoma group" (A4) (Romaschenko \& al., 2010).

According to the current dataset the sister-group relationships between Jarava s.str. and Nassella remain unsupported. In previous phylogenetic analyses the recently described Amelichloa (Arriaga \& Barkworth, 2006) was found to be embedded within Nassella (Barkworth \& al., 2008; Romaschenko \& al., 2008, 2010), or sister to Nassella as in our present analysis using a smaller dataset (Figs. 1-2). However, these relationships are not consistent with the LEP pattern where Nassella has fundamental and silica cells that are compressed and undifferentiated forming a ladder-like LEP (Fig. 4T) and Amelichloa has MLP with well developed silica bodies and associated cork cells (Fig. 4S). Species of Amelichloa have relatively long and hairy paleas with well-developed veins, features shared with members of the "Eriocoma" and "Pseudoeriocoma groups", and Stipa sect. Ptilostipa. Along with Pappostipa, the phylogenetic affiliation of Amelichloa represents one of the remaining puzzles in the evolutionary history of Stipeae, where the molecular evidence is at variance with established morphological patterns.

Lemma epidermal pattern polarized by the molecular data. - The utility of lemma epidermal patterns for phylogenetic studies of Stipeae as postulated by Tzvelev (1977), Thomasson $(1978,1980,1982,1985)$, and Barkworth \& Everett (1987), has never been questioned. In contrast, many gross morphological floret characters traditionally used in determining taxonomic or phylogenetic inferences in this tribe (i.e., length and indumentum of the awn; size and shape of the lemma; and sharpness of the callus; Freitag, 1975, 1985; Tzvelev, 1975), evidently have evolved independently many times within Stipeae. Our results reinforce these suggestions since these adaptive traits are not consistent within any recovered clades but are found within many lineages.

One test of our phylogenetic hypotheses is to compare the distribution of phylogenetically conservative morphological and anatomical characteristics. In Poaceae many characteristics involved in adaptations to dispersal and seedling establishment 
are relatively prone to parallelism, convergence, and even reversal. For example, awns and points of insertion of awns, pubescence patterns, number of florets per spikelet, size of florets, callus shape, elongated rhizomes and stolons, and annual life-cycle have all evolved repeatedly and, in many instances, reversed (Barkworth \& Everett, 1987; Davidse, 1987; Soreng \& al., 2007). However, we have found evolutionarily conservative anatomical characteristics that are consistent with molecular phylogenetic hypotheses and these support our interpretations. The phylogenetic trees presented in this paper effectively polarize the distribution of lemma epidermal characteristics (Figs. 1-2). We provide evidence that the SLP with long, often deeply sinuate fundamental cells is the ancestral state in Stipeae. In its general form this same LEP is common outside of Stipeae (Thomasson, 1986; Peterson, 1989; Valdes-Reyna \& Hatch, 1991; Columbus, 1996; Snow, 1996; Finot \& al., 2006; Liu \& al., 2010) while MLP and ladder-like LEP are not otherwise known within Pooideae. Within Stipeae (ignoring Pappostipa for the moment) the SLP is present in Macrochloa, SL1, SL2, and SL3 (Fig. 1) up to the point of divergence of the AC where it is replaced by the MLP with often short fundamental cells and abundant silica bodies. Within AC there are no known reversals to the ancestral condition.

No dataset examined so far has provided evidence for a single, initial bifurcation between Stipeae with SLP grasses (SL1, SL2, SL3; Fig. 3A-Y) and the AC, which possess MLP (Fig. 4A-T). More likely, three to six lineages with SLP diverged independently before the origin of the AC clade. Stipa s.l., Piptatherum s.l., and Achnatherum s.l. were revealed in the current study as polyphyletic based on molecular data and their LEP. Only a few species in these three genera are evidently misclassified as evidenced by LEP types, and we have tentatively provided new names or group names on the trees to identify these. Stipa pennata (type) and Achnatherum calamagrostis (type) reside firmly in the SLP and the MLP, respectively. Primary stepwise divergence of several SLP lineages leading to the divergence of the $\mathrm{AC}$ is marked by newly acquired features of the lemma and this polarizes the LEP distribution in Stipeae in such a way that the achnatheroid grasses are clearly derived from among the SLP lineages.

Within the AC a few achnatheroid taxa vary in their MLP, and these can be interpreted as transitional from unordered SLP to the typical and more common MLP. For instance, in Celtica the fundamental cells are long, and have thick walls but they are considered to represent MLP since the fundamental cells' walls are straight as in other species in AC. The "Miliacea group" (Piptatherum miliaceum, P. thomasii) is similar to Celtica but has thin walls. In Stipa capensis ("Stipella") the fundamental cells are somewhat sinuous-walled and thick but are short as in the MLP.

Within AC a highly modified ladder-like LEP is found only in species of Nassella wherein the silica cells are lacking silica bodies and are almost indistinguishable from the longitudinally highly compressed fundamental cells. Since the clade of Nassella is deeply nested within AC and all other branches have MLP it is apparent that the Nasselloid ladder-like LEP is derived from the MLP.
Biogeography. - Despite the deep history of unambiguous Stipeae fossils in the Miocene, and possible Stipeae fossils from the mid-Oligocene of North America (Elias, 1942; Galbreath, 1974; Thomasson, 1978, 1980, 1987, 2005), the biogeographical history within Stipeae remains difficult to interpret. However, the plastid tree (Fig. 1) provides some clues. We are reasonably confident that Macrochloa is sister to the rest of the extant elements of Stipeae. Today Macrochloa consists of a single Mediterranean species, but the nearest relatives of Stipeae come from all over the world so extinction in other regions may have left us only this one Mediterranean element. Several clades within Stipeae are evidently geographically pure. The ASL1 and MAC clades are strictly New World. CAC is strictly Old World with a probable expansion into Australasia and Africa. The "Timouria group" is strictly South-East Asian. As for the SL1/ESL clade, the North American monotypic genus Oryzopsis belies the otherwise strictly Eurasian nature of the clade. As for the SL3 clade, Achnatherum stillmanii of North America is sister to a strictly Eurasian group of Piptatherum s.str. At a minimum, if we interpret Fig. 1 at face value, starting with Macrochloa in the Mediterranean, there are four evident dispersal events into the New World, and one to Australasia. For the reverse direction, of Stipeae dispersal to the Old World from the New World, we must postulate at least six dispersal events. However, along the backbone of the tree (Fig. 1) there are few unambiguous directions of dispersal or patterns of vicariance, particularly as there is only weak support at several pivotal nodes.

Chromosome numbers. - There is much uncertainty about the pleisomorphic base chromosome number in Pooideae. Outside of Stipeae, Brachyelytrum has a base chromosome number of $x=11(2 n=22)$, Nardus of $x=13(2 n=26)$, and Lygeum of $x=10(2 n=40$; see Appendix 3 for list of chromosome numbers). Within Phaenospermateae (sensu Schneider $\&$ al., 2009), counts of $x=7(2 n=14)$ have been reported for Danthoniastrum and Duthiea (Kozuharov \& Petrova, 1991; Watson \& Dallwitz, 1992) and $x=12(2 n=24)$ is known for Phaenosperma and Stephanachne. Meliceae have base chromosome numbers of $x=9,10$, and perhaps 12 . The base number is ambiguous for Diarrheneae where $2 n$ numbers are [36?], 38, and 60 , and $x$ might be 5, 6, [9?] 10, or 19. Only in the tribes Bromeae, Triticeae, and Poeae s.l. (the core Pooideae) the base chromosome number is obviously $x=7$.

Chromosome numbers have been reported for more than 120 species of Stipeae, 86 of which we included in our study (see Appendix 3). Of these 120 about 26 appear to be diploid with possible base numbers of $x=7,8,9,10,11$, or 12 . Despite the high frequency of polyploid series in Stipeae three hypotheses have been suggested for their base chromosome number: $x=7$ (Tzvelev, 1977), $x=12$ (Avdulov, 1931), and $x$ $=11$ (Clayton \& Renvoize, 1986; Hilu, 2004). The possibility that one of these numbers might be basal for the entire Poaceae has also been thoroughly discussed (Avdulov, 1931; De Wet, 1987; Hilu, 2004; Hubbard, 1948; Hunziker \& Stebbins, 1987; Raven, 1975; Stebbins, 1982, 1985).

The evidence for $x=7$ being the original base chromosome number in Stipeae is weak, and is contradicted by the presence 
of this possible base number in only three highly derived lineages of our plastid tree. Eleven counts possibly based on $x=$ 7 are present in AC (CAC and Nassella) and in Piptochaetium; all of these are polyploid, and five are $2 n=28$ (tetraploid).

Chromosome numbers in most other Stipeae represent different polyploid series based on $x=12$ or $x=11$. A base number of $x=12$ is the most common one among diploids in Stipeae, occurring in AC and in all SL lineages. In our dataset $2 n=24$ is recorded for Old World Achnatherum (CAC; A1) and Piptatheropsis, Piptatherum s.str., "Miliacea" and "Virescens groups". Despite this, there are few polyploids that are interpretable as being based on $x=12$. Several taxa with $2 n=48$ are most likely tetraploid, but most of the other taxa are more comfortably interpreted as tetraploid based on $x=9$ (at $2 n=$ 36), rather than as triploids based on $x=12$.

A base of $x=11$ also occurs widely among diploids, occurring in Aciachne, Piptatheropsis, and Ptilagrostis of the SL lineages. Several studies (Johnson, 1945; Probatova \& Sokolovskaya, 1980) confirmed the presence of a stable $2 n=$ 22 karyotype in Stipeae that spans almost the entire SL1 clade including its Eurasian (ESL) and American (ASL) subclades. In Stipa s.str. 45 species have counts of $2 n=44$ (tetraploid). Fifteen other diploid and polyploid taxa of SL and AC lineages are easily interpreted as tetraploids or hexaploids based on $x=$ 11, including several New World species of Achnatherum and Hesperostipa, and one species each of the following genera: Anemanthele, Jarava s.l. (J. plumulosa), Macrochloa, Nassella, and Pappostipa. Old World Achnatherum sibiricum is $2 n=22$ and 24 ( $x=11$ and 12). Piptochaetium fimbriatum has counts of $2 n=42$ and 44, and could be interpreted as $x=7$ (as are other species of Piptochaetium with $2 n=28$ ); or as initially $x=11$, and having lost two chromosomes.

None of the possible phylogenetic scenarios represented in our analyses (Figs. 1-2) supports a single event of descending or ascending disploidy in Stipeae between $x=11$ and 12. In the plastid phylogeny the chromosome number patterns in Stipeae begin with Macrochloa which is known to have $2 n=24,36,40$, 64 , and 66 , as well as 72 . These could be based on $x=8,10,11$ or 12 , or even 16 for this species. The first split between $x=11$ and $x=12$ in Stipeae is more confidently associated with the crown node of SL1. Examination of the SL1 clade reveals an $x$ $=11$ series that spans the entire ASL clade, occurring in diploid Piptatheropsis, one polyploid Piptochaetium ( $x=7$ is also possible for the genus), tetraploid Hesperostipa, and hexaploid and octoploid Pappostipa. A second split between $x=11$ and $x=$ 12 in SL1 could be associated with the crown node for the ESL clade. In this case, an $x=11$ series is represented by tetraploid Stipa and diploid Ptilagrostis. An $x=12$ series is represented by a group of stout, rhizomatous to tussock-forming SLP taxa with putative tetraploid $(2 n=48)$ karyotypes. The latter group includes Ampelodesmos and "Neotrinia" $(2 n=42,48)$. The second SLP lineage (SL2) encompasses putative tetraploidsPatis coreana $(2 n=46$; Tateoka, 1986$)$ and $P$. racemosa $(2 n=$ 46; Johnson, 1945). The third SLP lineage, SL3, is represented by the diploid Old World genus Piptatherum s.str. with $2 n=24$ ( $x=12$ in all five species with counts). Thus, there is no clear case here for $x=11$ over $x=12$.
Recent studies have provided new insight into the evolution of the grass genome (Paterson \& al., 2004; Salse \& al., 2004, 2008, 2009; Wei \& al., 2007), including the facility of certain chromosomes to fuse and possibly split. These studies illustrate that earlier karyological studies can often be usefully interpreted in light of a molecular phylogeny (Levin, 2002). Given the data we have, $x=12$ seems more likely to be the base chromosome number for Stipeae, but $x=11$ cannot be ruled out.

\section{- CONCLUSION}

Based on analyses presented in this paper and on unpublished data 33 groups that we envision to represent genera within Stipeae are listed in Table 1. Eleven of these groups currently are monotypic: Ampelodesmos, Anemanthele, Celtica, "Inaequiglumes", Macrochloa, "Neotrinia", Oryzopsis, Orthoraphium, Psammochloa, "Stillmania", and "Stipella". Thirteen of these generic groups are distributed in North America, ten are found in Asia, nine are in South America, and seven are in Europe. Stipa still might be the largest genus with between 110 and 232 species (depending on how finely the species are divided) distributed in Eurasia; Nassella has approximately 117 species distributed in the Americas; and Austrostipa has 62 species endemic to Australia and New Zealand (Klokov \& Ossycznjuk, 1976; Martinovský, 1980; Moraldo, 1986; Edgar \& Connor, 2000; Barkworth, 2007; Everett \& al., 2009; Soreng \& al., 2009).

\section{ACKNOWLEDGMENTS}

We thank the following organizations and people: the Smithsonian Institution's Restricted Endowment Fund, the Scholarly Studies Program, Research Opportunities, Atherton Seidell Foundation, Biodiversity Surveys and Inventories Program, National Museum of Natural History-Small Grants, and Laboratory of Analytical Biology (LAB) all for financial support; Lee Weigt, Gabriel Johnson, Jeffrey Hunt, David Erickson, Kenneth Wurdack, and Andrea Ormon for support and consultation while working at LAB; the National Geographic Society Committee for Research and Exploration (grant number 808706) for field and laboratory support; the Fulbright Scholar Program to KR for a research visit to the Smithsonian Institution; the Komarov Botanical Institute, Russian Academy of Sciences for the opportunity to work with herbarium collections, and Nikolai Czvelev and Dmitry Geltman for consultation and permitting us to sample Stipeae specimens; Asuncion Cano Echevarría, Oscar Tovar Serpa†, Dorita Susanibar Cruz, María Isabel La Torre Acuy, Jenny Vanessa Rojas Fox, Isidoro Sánchez Vega, Socorro González Elizondo, Nancy RefulioRodríguez, Diego Leonel Salariato, Adela María Panizza, Fernando O. Zuloaga, and Stephan Beck for help with our field expeditions to Peru, Bolivia, and Argentina; Sun Hang for help doing fieldwork in China; Sabine Miehe for providing samples from China, Hidehisa Koba for providing samples from Japan, Samuel Pyke for providing samples from North Africa, and Jeffery M. Saarela for providing samples from North America; Michael Pirie, Ana Maria Cialdella, Osvaldo Morrone $\dagger$, and three anonymous reviewers for suggesting improvements to the manuscript. 


\section{LITERATURE CITED}

Arriaga, M.O. \& Barkworth, M.E. 2006. Amelichloa, a new genus in the Stipeae (Poaceae). Sida 22: 145-149.

Avdulov, N.P. 1931. Karyo-systematische Untersuchung der Familie Gramineen. Trudy Prikl. Bot. Suppl. 43: 1-352.

Bain, J.F. \& Jansen, R.K. 2006. A chloroplast DNA hairpin structure provides useful phylogenetic data within tribe Senecioneae (Asteraceae). Canad. J. Bot. 84: 862-868.

Barber, J.C., Hames, K.A., Cialdella, A.M., Giussani, L.M. \& Morrone, O. 2009. Phylogenetic relationships of Piptochaetium Presl (Poaceae: Stipeae) and related genera as reconstructed from nuclear and chloroplast datasets. Taxon 58: 375-380.

Barker, N.P., Linder, H.P. \& Harley, E.H. 1999. Sequences of the grass-specific insert in the chloroplast rpoC2 gene elucidate generic relationships of the Arundinoideae (Poaceae). Syst. Bot. 23: 327-350.

Barkworth, M.E. 1983. Ptilagrostis in North America and its relationship to other Stipeae (Gramineae). Syst. Bot. 8: 395-419.

Barkworth, M.E. 1990. Nassella (Gramineae, Stipeae): Revised interpretation and nomenclatural changes. Taxon 39: 597-614.

Barkworth, M.E. 1993. North American Stipeae (Gramineae): Taxonomic changes and other comments. Phytologia 74: 1-25.

Barkworth, M.E. 2007. Stipeae. Pp. 109-186 in: Flora of North America Editorial Committee (eds.), Flora of North America north of Mexico, vol. 25, Magnoliophyta: Commelinidae (in part): Poaceae, part 1. New York: Oxford University Press.

Barkworth, M.E. \& Everett, J. 1987. Evolution in Stipeae: Identification and relationship of its monophyletic taxa. Pp. 251-264 in: Soderstrom, T.R., Hilu, K.W., Campbell, C.S. \& Barkworth, M.E (eds.), Grass systematics and evolution. Washington, D.C.: Smithsonian Institution Press.

Barkworth, M.E. \& Torres, M.A. 2001. Distribution and diagnostic characters of Nassella (Poaceae: Stipeae). Taxon 50: 439-468.

Barkworth, M.E., Arriaga, M.O., Smith, J.F. Jacobs, S.W.L., ValdesReyna, J. \& Bushman, B.S. 2008. Molecules and morphology in South American Stipeae (Poaceae). Syst. Bot. 33: 719-731.

Baum, B.R. 1973. The genus Danthoniastrum, about its circumscription, past and present status, and some taxonomic principles. Österr. Bot. Z. 122: 51-57.

Bor, N.L. 1970. Graminae-Stipeae. Pp. 488-505 in: Rechinger, K.H (ed.), Flora Iranica, no. 70/30. Graz: Akademische Druck- und Verlagsanstalt.

Bouchenak-Khelladi, Y., Salamin, N., Savolainen, V., Forest, F., Van der Bank, M., Chase, M.W. \& Hodkinson, T.R. 2008. Large multi-gene phylogenetic trees of the grasses (Poaceae): Progress towards complete tribal and generic level sampling. Molec. Phylogenet. Evol. 47: 488-505.

Catalán, P., Kellogg, E.A. \& Olmstead, R.G. 1997. Phylogeny of Poaceae subfamily Pooideae based on chloroplast $n d h F$ gene sequences. Molec. Phylogenet. Evol. 8: 150-166.

Catalano, S.A., Saidman, B.O. \& Vilardi, J.C. 2009. Evolution of small inversions in chloroplast genome: A case study from a recurrent inversion in angiosperms. Cladistics 25: 93-104.

Chiapella, J. 2008. On Jarava, or putting the cart before the horse. Taxon 57: 695-697.

Cialdella, A.M. \& Giussani, L.M. 2002. Phylogenetic relationships of the genus Piptochaetium (Poaceae, Pooideae, Stipeae): Evidence from morphological data. Ann. Missouri Bot. Gard. 89: 305-336.

Cialdella, A.M., Giussani, L.M., Aagesen, L., Zuloaga, F.O. \& Morrone, O. 2007. A phylogeny of Piptochaetium (Poaceae: Pooideae: Stipeae) and related genera based on a combined analysis including trnL-F, rpl16, and morphology. Syst. Bot. 32: 545-559.

Cialdella, A.M., Salariato, D.L., Aagesen, L., Giussani, L.M., Zuloaga, F.O. \& O. Morrone. 2010. Phylogeny of American Stipeae (Poaceae): An approach based on molecular and morphological characters. Cladistics 26: 563-578.
Clark, L.G., Zhang, W. \& Wendel, J.F. 1995. A phylogeny of the grass family (Poaceae) based on $n d h F$ sequence data. Syst. Bot. 20: 436-460.

Clayton, W.D. \& Renvoize, S.A. 1986. Genera graminum. Kew Bull. Addit. Ser. 13: 1-389.

Columbus, J.T. 1996. Lemma micromorphology, leaf blade anatomy, and phylogenetics of Bouteloua, Hilaria, and relatives (Gramineae: Chloridoideae: Boutelouinae). Ph.D. dissertation, University of California, U.S.A.

Columbus, J.T. \& Smith, J.P., Jr. 2010. Nomenclatural changes for some grasses in California and the Muhlenbergia clade (Poaceae). Aliso 28: 65-67.

Davidse, G. 1987. Fruit dispersal in the Poaceae. Pp. 143-155 in: Soderstrom, T.R., Hilu, K.W., Campbell, C.S. \& Barkworth, M.E. (eds.), Grass systematics and evolution. Washington, D.C.: Smithsonian Institution Press.

Davis, J.I. \& Soreng, R.J. 1993. Phylogenetic structure in the grass family (Poaceae) as inferred from chloroplast DNA restriction site variation. Amer. J. Bot. 80: 1444-1454.

Davis, J.I. \& Soreng, R.J. 2007. A preliminary phylogenetic analysis of the grass subfamily Pooideae (Poaceae), with attention to structural features of the plastid and nuclear genomes, including an intron loss in GBSSI. Aliso 23: 335-348.

Davis, J.I. \& Soreng, R.J. 2010. Migration of endpoints of two genes relative to boundaries between regions of the plastid genome in the grass family (Poaceae). Amer. J. Bot. 97: 874-892.

De Wet, J.M.J. 1987. Hybridization and polyploidy in the Poaceae. Pp. 188-194 in: Soderstrom, T.R., Hilu, K.W., Campbell, C.S. \& Barkworth, M.E. (eds.), Grass systematics and evolution. Washington D.C.: Smithsonian Institution Press.

Decker, H.F. 1964. Affinities of the grass genus Ampelodesmos. Brittonia 16: 76-79.

Döring, E. 2009. Molekulare Phylogenie der Hafer-Gräser (Poaceae: Pooideae: Aveneae). Ph.D. dissertation, Martin-Luther-Universität Halle-Wittenberg, Germany.

Döring, E., Schneider, J., Hilu, K.W. \& Röser, M. 2007. Phylogenetic relationships in the Aveneae/Poeae complex (Pooideae, Poaceae). Kew Bull. 62: 407-424.

Dorn, R.D. 2001. Vascular plants of Wyoming, 3rd ed. Cheyenne: Mountain West Publishing.

Downie, S.R. \& Palmer, J.D. 1992. Restriction site mapping of the chloroplast DNA inverted repeat: A molecular phylogeny of the Asteridae. Ann. Missouri Bot. Gard. 79: 266-283.

Edgar, E. \& Connor, H.E. 2000. Flora of New Zealand, vol. 5, Gramineae. Lincoln: Manaaki Whenua Press.

Elias, M.K. 1942. Tertiary prairie grasses and other herbs from the High Plains. Special Pap. Geol. Soc. Amer. 41: 1-176.

Ellis, R.P. 1979. A procedure for standardizing comparative leaf anatomy in the Poaceae. II. The epidermis as seen in surface view. Bothalia 12: 641-671.

Everett, J., Jacobs, S.W.L. \& Nairn, L. 2009. Austrostipa. Pp. 15-60 in: Wilson, A. (ed.), Flora of Australia, vol. 44A, Poaceae 2. Melbourne, Canberra: CSIRO Publishing.

Finot, V.L., Baeza, C.M. \& Matthei, O. 2006. Micromorfología de la epidermis de la lemma de Trisetum y géneros afines (Poaceae, Pooideae). Darwiniana 44: 32-57.

Freitag, H. 1975. The genus Piptatherum (Gramineae) in Southwest Asia. Notes Roy. Bot. Gard. Edinburgh 33: 341-408.

Freitag, H. 1985. The genus Stipa (Gramineae) in Southwest and South Asia. Notes Roy. Bot. Gard. Edinburgh 42: 355-489.

Galbreath, E.C. 1974. Stipoid grass "seeds" from the Oligocene and Miocene deposits of northeastern Colorado. Trans. Illinois State Acad. Sci. 67: 366-368.

Goldman, N., Anderson, J.P. \& Rodrigo, A.G. 2000. Likelihoodbased tests of topologies in phylogenetics. Syst. Biol. 49: 652670.

GPWG (Grass Phylogeny Working Group). 2001. Phylogeny and 
subfamilial classification of the grasses (Poaceae). Ann. Missouri Bot. Gard. 88: 373-457.

Hall, T.A. 1999. BioEdit: A user-friendly biological sequence alignment editor and analysis program for Windows 95/98/NT. Nucl. Acids Symp. Ser. 41: 95-98.

Hilu, K.W. 2004. Phylogenetics and chromosomal evolution in the Poaceae (grasses). Austral. J. Bot. 52: 13-22.

Hilu, K.W., Lawrence, A.A. \& Liang, H. 1999. Phylogeny of Poaceae inferred from matK sequences. Ann. Missouri Bot. Gard. 86: 835-851

Hitchcock, A.S. 1925a. The North American species of Stipa. Contr. U.S. Natl. Herb. 24: 215-262.

Hitchcock, A.S. 1925b. Synopsis of the South American species of Stipa. Contr. U.S. Natl. Herb. 24: 263-289.

Hitchcock, A.S. 1935. 96. Stipa; 97. Oryzopsis; 98. Piptochaetium. Pp. 406-431 in: North American flora, vol. 17(5-6). New York: New York Botanical Garden.

Hitchcock, A.S. 1951. Manual of grasses of the United States (ed. 2, revised by A. Chase). Misc. Publ. U.S.D.A. 200: 1-1051.

Holub, J. 1998. Reclassifications and new names in vascular plants 1. Preslia 70: 97-122.

Hsiao, C., Jacobs, S.W.L., Chatterton, N.J. \& Asay, K.H. 1999. A molecular phylogeny of the grass family (Poaceae) based on the sequences of nuclear ribosomal DNA (ITS). Austral. Syst. Bot. 11: $667-688$

Hubbard, C.E. 1948. Gramineae. Pp. 284-348 in: Hutchinson, J. (ed.), British flowering plants. London: Gawthorn.

Huelsenbeck, J.P. \& Ronquist, F.R. 2001. MrBAYES: Bayesian inference of phylogenetic trees. Bioinformatics 17: 754-755.

Huelsenbeck, J.P., Hillis, D.M. \& Jones, R. 1995. Parametric bootstrapping in molecular phylogenetics: Applications and performance. Pp. 19-45 in: Ferraris, J.D. \& Palumbi, S.R. (eds.), Molecular zoology: Advances, strategies, and protocols. New York: Wiley-Liss.

Humphreys, A.M., Pirie, M.D. \& Linder, H.P. 2010. A plastid tree can bring order to the chaotic generic taxonomy of Rytidosperma Steud. s.l. (Poaceae). Molec. Phylogenet. Evol. 55: 911-928.

Hunziker, J.H. \& Stebbins, G.L. 1987. Chromosomal evolution in the Gramineae. Pp. 179-187 in: Soderstrom, T.R., Hilu, K.W., Campbell, C.S. \& Barkworth, M.E. (eds.), Grass systematics and evolution. Washington, D.C.: Smithsonian Institution Press.

Jacobs, S.W.L. \& Everett, J. 1996. Austrostipa, a new genus, and new names for Australasian species formerly included in Stipa (Gramineae). Telopea 6: 579-595.

Jacobs, S.W.L., Bayer, R., Everett, J., Arriaga, M.O., Barkworth, M.B., Sabin-Badereau, A., Torres, M.A., Vázquez, F.M. \& Bagnall, N. 2007. Systematics of the tribe Stipeae using molecular data. Aliso 23: 349-361.

Jacobs, S.W.L., Everett, J., Barkworth, M.E. \& Hsiao, C. 2000. Relationships within the Stipeae (Gramineae). Pp. 75-82 in: Jacobs, S.W.L. \& Everett, J. (eds.), Grasses: Systematics and evolution. Collingwood: CSIRO Publishing.

Johnson, B.L. 1945. Cytotaxonomic studies in Oryzopsis. Bot. Gaz. 107: 1-32.

Johnson, L.A. \& Soltis, D.E. 1995. Phylogenetic inference in Saxifragaceae sensu stricto and Gilia (Polemoniaceae) using matK sequences. Ann. Missouri Bot. Gard. 82: 149-175.

Kelchner, S.A. \& Wendel, J.F. 1996. Hairpins create minute inversions in noncoding regions of chloroplast DNA. Curr. Genet. 30: 259-262.

Kim, K.J. \& Lee, H.L. 2005. Widespread occurrence of small inversions in the chloroplast genomes of land plants. Molec. Cells 19: 104-113.

Kimura, M. 1981. Estimation of evolutionary distances between homologous nucleotide sequences. Proc. Natl. Acad. Sci. U.S.A. 78: 454-458

Klokov, M.V. \& Ossycznjuk, V. 1976 [“1975”]. Stipeae Ucrainicae. Novosti Sist. Vyssh. Nizsh. Rast. 1975: 7-92.
Kozuharov, S.I. \& Petrova, A.V. 1991. Chromosome numbers of Bulgarian angiosperms. Fitologiya 39: 72-77.

Kress, W.J. \& Erickson, D.L. 2008. DNA barcodes: Genes, genomics, and bioinformatics. Proc. Natl. Acad. Sci. U.S.A. 105: 2761-2762.

Kress, W.J., Erickson, D.L., Jones, F.A., Swenson, N.G., Perez, R., Sanjur, O. \& Bermingham, E. 2009. Plant DNA barcodes and a community phylogeny of a tropical forest dynamics plot in Panama. Proc. Natl. Acad. Sci. U.S.A. 106: 18621-18626.

Kress, W.J., Wurdack, K.G., Zimmer, E.A., Weigt, L.A. \& Janzen, D.H. 2005. Use of DNA barcodes to identify flowering plants. Proc. Natl. Acad. Sci. U.S.A. 102: 8369-8374.

Lehtonen, S., Myllys, L. \& Huttunen, S. 2009. Phylogenetic analysis of non-coding plastid DNA in the presence of short inversions. Phytotaxa 1: 3-20.

Levin, D.A. 2002. The role of chromosomal change in plant evolution. New York: Oxford University Press.

Liu, Q., Zhang, D.X. \& Peterson, P.M. 2010. Lemma micromorphological characters in the Chloridoideae (Poaceae) optimized on a molecular phylogeny. S. African J. Bot. 76: 196-209.

Maddison, W.P. \& Maddison, D.R. 2009. Mesquite: A modular system for evolutionary analysis, version 2.72 . http://mesquiteproject.org.

Martinovský, J.O. 1980. Stipa L. Pp. 247-252 in: Tutin, T.G., Heywood, V.H., Burges, N.A., Moore, D.M, Valentine, D.H., Walters, S.M. \& Webb, D.A. (eds.), Flora europaea, vol. 5, Alismataceae to Orchidaceae (Monocotyledones). Cambridge: Cambridge University Press.

Mathews, S., Spangler, R.E., Mason-Gamer, R.J. \& Kellogg, E.A. 2002. Phylogeny of Andropogoneae inferred from phytochrome B, GBSSI, and ndhF. Int. J. Pl. Sci. 163: 441-450.

Moraldo, B. 1986. Il genere Stipa L. (Gramineae) in Italia. Webbia 40: 203-278.

Nylander, J.A. 2002. MrModeltest, version 1.1b. Program distributed by the author. Sweden: Uppsala University, Department of Systematic Zoology.

Ohwi, J. 1941. Stipeae (Gramineae) of Japan, Manchuria, and Northern China. J. Jap. Bot. 17: 399-405.

Ohwi, J. 1942. Gramina Japonica IV. Acta Phytotax. Geobot. 11: 181.

Ohwi, J. 1953. New names and new combinations adopted in my "Flora of Japan". Bull. Natl. Sci. Mus. Tokyo 33: 66-90.

Parodi, L.R. 1944. Revisión de las gramíneas australes americanas del género Piptochaetium. Revista Mus. La Plata, Secc. Bot. 6: 213-310.

Parodi, L.R. 1946. The Andean species of the genus Stipa allied to Stipa obtusa. Blumea 3: 63-70.

Parodi, L.R. 1947. Las especies de Gramíneas del género Nassella de la Argentina y Chile. Darwiniana 7: 369-395.

Parodi, L.R. 1960. Las especies de Stipa del subgenero Pappostipa de la Argentina y Chile. Revista Argent. Agron. 27: 65-106.

Paterson, A.H., Bowers, J.E. \& Chapman, B.A. 2004. Ancient polyploidization predating divergence of the cereals, and its consequences for comparative genomics. Proc. Natl. Acad. Sci. U.S.A. 101: 9903-9908.

Peñailillo, P. 1996. Anatherostipa, un nuevo género de Poaceae (Stipeae). Gayana Bot. 53: 277-284.

Peñailillo, P. 2002. El género Jarava Ruiz et Pav. (Stipeae-Poaceae): Delimitación y nuevas combinaciones. Gayana Bot. 59: 27-34.

Peñailillo, P. 2003. Anatherostipa. Pp. 109-110 in: Soreng, R.J., Peterson, P.M., Davidse, G., Judziewicz, E.J., Zuloaga, F.O., Filgueiras, T.S. \& Morrone, O. (eds.), Catalogue of New World Grasses (Poaceae): IV. Subfamily Pooideae. Contributions from the United States National Herbarium 48. Washington, D.C.: Smithsonian Institution.

Peñailillo, P. 2005. Los géneros nativos de la tribu Stipeae (Poaceae, Pooideae) en Chile. Teoría 14: 125-140.

Peterson, P.M. 1989. Lemma micromorphology in the annual Muhlenbergia (Poaceae). S. W. Naturalist 34: 61-71.

Peterson, P.M., Romaschenko, K. \& Johnson, G. 2010a. A classification of the Chloridoideae (Poaceae) based on multi-gene phylogenetic trees. Molec. Phylogenet. Evol. 55: 580-598. 
Peterson, P.M., Romaschenko, K. \& Johnson, G. 2010b. A phylogeny and classification of the Muhlenbergiinae (Poaceae: Chloridoideae: Cynodonteae) based on plastid and nuclear DNA sequences. Amer. J. Bot. 97: 1532-1554.

Posada, D. \& Crandall, K.A. 1998. MODELTEST: Testing the model of DNA substitution. Bioinformatics 14: 817-818.

Probatova, N.S. \& Sokolovskaya, A.P. 1980. A karyotaxonomic study of the grasses of the Altai Mts. Bot. Zhurn. 65: 509-520.

Raven, P.H. 1975. The bases of angiosperm phylogeny: Cytology. Ann. Missouri Bot. Gard. 62: 724-764.

Roig, F.A. 1964. Las Gramíneas Mendocinas del género Stipa. I. Taxonomía. Revista Fac. Ci. Agrar. Univ. Nac. Cuyo 11: 3-110.

Rojas P., F. 1997. New species and new combinations for the tribe Stipeae (Poaceae) in Bolivia. Gayana, Bot. 54: 163-182.

Romaschenko, K., Peterson, P.M., Soreng, R.J., Futoma, O. \& Susanna, A. 2011. Phylogenetics of Piptatherum s.1. (Poaceae: Stipeae): Evidence for a new genus, Piptatheropsis, and resurrection of Patis. Taxon 60: 1703-1716.

Romaschenko, K., Peterson, P.M., Soreng, R.J., Garcia-Jacas, N., Futoma, O. \& Susanna, A. 2008. Molecular phylogenetic analysis of the American Stipeae (Poaceae) resolves Jarava sensu lato polyphyletic: Evidence for a new genus, Pappostipa. J. Bot. Res. Inst. Texas 2: 165-192.

Romaschenko, K., Peterson, P.M., Soreng, R.J., Garcia-Jacas, N. \& Susanna, A. 2010. Phylogenetics of Stipeae (Poaceae: Pooideae) based on plastid and nuclear DNA sequences. Pp. 513-539 in: Seberg, O., Petersen, G., Barfod, A.S. \& Davis, J.I. (eds.), Diversity, phylogeny, and evolution in the monocotyledons. Denmark: Aarhus University Press.

Ronquist, F., Huelsenbeck, J.P. \& Van der Mark, P. 2005. MrBayes 3.1 manual, draft 2/26/2005. http://mrbayes.csit.fsu.edu/mb3.1 manual.pdf.

Roshevits, R.Yu. 1934. Gramineae. Pp. 1-622 in: Roshevits, R.Yu \& Shishkin, B.K. (eds.), Flora of the U.S.S.R., vol. 2. Jerusalem: Israel Program for Scientific Translations, 1963.

Roshevits, R.Yu. 1916. Gramineae III. Pp. 107-191 in: Fedtschenko, B.A. (ed), Flora Aziatskoj Rossii, vol. 12. St. Petersburg: Tipographia Iu. Erlikh.

Roshevits, R.Yu. 1951. De genere Piptatherum P.B. notae criticae. Bot. Mater. Gerb. Bot. Inst. Komarova Akad. Nauk S.S.S.R. 14: 78-129.

Rychlik, W. 2009. OLIGO primer analysis software, version 7. Molecular Biology Insights, Inc., Cascade, Colorado, U.S.A. http:// oligo.net/.

Salse, J., Abrouk, M., Bolot, S., Guilhot, N., Courcelle, E., Faraut, T., Waugh, R., Close, T.J., Messing, J. \& Feuillet, C. 2009. Reconstruction of monocotyledoneous proto-chromosomes reveals faster evolution in plants than in animals. Proc. Natl. Acad. Sci. U.S.A. 106: 14908-14913.

Salse, J., Bolot, S., Throude, M., Jouffe, V., Piegu, B., Quraishi, U.M., Calcagno, T., Cooke, R., Delseny, M. \& Feuillet, C. 2008. Identification and characterization of shared duplications between rice and wheat provide new insight into grass genome evolution. Pl. Cell 20: 11-24.

Salse, J., Piegu, B., Cooke, R. \& Delseny, M. 2004. New in silico insight into the synteny between rice (Oryza sativa $\mathrm{L}$.) and maize (Zea mays L.) highlights reshuffling and identifies new duplications in the rice genome. Plant J. 38: 396-409.

Sang, T., Crawford, D.J. \& Stuessy, T.F. 1997. Chloroplast DNA phylogeny, reticulate evolution, and biogeography of Paeonia (Paeoniaceae). Amer. J. Bot. 84: 1120-1136.

Schneider, J., Döring, E., Hilu, K.W. \& Röser, M. 2009. Phylogenetic structure of the grass subfamily Pooideae based on comparison of plastid matK gene-3'trnK exon and nuclear ITS sequences. Taxon 58: 405-424.

Shaw, J., Lickey, E.B., Beck, J.T., Farmer, S.B., Liu, W., Miller, J., Siripun, K.C., Winder, C.T., Schilling, E.E. \& Small, R.L. 2005. The tortoise and hare II: Relative utility of 21 noncoding chloroplast DNA sequences for phylogenetic analysis. Amer. $J$. Bot. 92: 142-166.

Shaw, J., Lickey, E.B., Beck, J.T., Schilling, E.E. \& Small, R.L. 2007. Comparison of the whole chloroplast genome sequences to choose noncoding regions for phylogenetic studies in angiosperms: The tortoise and the hare III. Amer. J. Bot. 94: 275-288.

Snow, N. 1996. The phylogenetic utility of lemmatal micromorphology in Leptochloa s.l. and related genera in subtribe Eleusininae (Poaceae, Chloridoideae, Eragrostideae). Ann. Missouri Bot. Gard. 83: 504-529.

Soreng, R.J. \& Davis, J.I. 1998. Phylogenetics and character evolution in the grass family (Poaceae): Simultaneous analysis of morphological and chloroplast DNA restriction site character sets. Bot. Rev. (Lancaster) 64: 1-85.

Soreng, R.J. \& Davis, J.I. 2000. Phylogenetic structure in Poaceae subfamily Pooideae as inferred from molecular and morphological characters: Misclassification versus reticulation. Pp. 61-74 in: Jacobs, S.W.L. \& Everett, J. (eds.), Grasses: Systematics and evolution. Collingwood: CSIRO Publishing.

Soreng, R.J., Davidse, G., Peterson, P.M, Zuloaga, F.O., Judziewicz, E.J., Filgueiras, T.S. \& Morrone, O. 2011. Classification of New World grasses. http://www.tropicos.org/projectwebportal.aspx?pa gename $=$ ClassificationNWG\&projectid $=10$.

Soreng, R.J., Davis, J.I \& Voionmaa, M.A. 2007. A phylogenetic analysis of Poaceae tribe Poeae sensu lato based on morphological characters and sequence data from three plastid-encoded genes: Evidence for reticulation, and a new classification for the tribe. Kew Bull. 62: 425-454.

Soreng, R.J., Peterson, P.M., Davidse, G., Judziewicz, E., Zuloaga, F.O., Filgueiras, T.S. \& Morrone, O. 2003. Catalogue of New World grasses (Poaceae): IV. Subfamily Pooideae. Contr. U.S. Natl. Herb. 48: 1-730.

Soreng, R.J., Peterson, P.M., Davidse, G., Judziewicz, E., Zuloaga, F.O., Filgueiras, T.S. \& Morrone, O. 2009. Catalogue of New World grasses (Poaceae). http://www.tropicos.org/Project/CNWG

Spegazzini, C. 1901. Stipeae platenses. Anales Mus. Nac. Montevideo 4: $1-173$.

Stanford, A.M., Harden, R. \& Parks, C.R. 2000. Phylogeny and biogeography of Juglans (Juglandaceae) based on matK and ITS sequence data. Amer. J. Bot. 87: 872-882.

Stebbins, G.L. 1982. Major trends of evolution in the Poaceae and their possible significance. Pp. 3-36 in: Estes, J.R., Tyrl, R.J. \& Brunken, J.N. (eds.), Grasses and grasslands: Systematics and ecology. Norman: University of Oklahoma Press.

Stebbins, G.L. 1985. Polyploidy, hybridization and the invasion of new habitats. Ann. Missouri Bot. Gard. 72: 824-832.

Swofford, D.L. 2000. PAUP*: Phylogenetic analysis using parsimony (*and other methods), version 4. Sunderland, Massachusetts: Sinauer.

Swofford, D.L., Olson, G.J., Waddell, P.J. \& Hillis, D.M. 1996. Phylogenetic inference. Pp. 407-514 in: Hillis, D.M., Moritz, C. \& Mable, BK. (eds.), Molecular Systematics., Sunderland, Massachusetts: Sinauer.

Taberlet, P., Gielly, L., Pautou, G. \& Bouvet, J. 1991. Universal primers for amplification of three non-coding regions of chloroplast DNA. Pl. Molec. Biol. 17: 1105-1109.

Tate, J.A. \& Simpson, B.B. 2003. Paraphyly of Tarasa (Malvaceae) and diverse origins of the polyploidy species. Syst. Bot. 28: 723-737.

Tateoka, T. 1986. Chromosome numbers in the tribe Stipeae (Poaceae) in Japan. Bull. Nation. Sci. Mus. Tokyo, B 12: 151-154.

Tavaré, S. 1986. Some probabilistic and statistical problems in analysis of DNA sequences. Pp. 57-86 in: Miura, R.M. (ed.), Some mathematical questions in biology: DNA sequence analysis. Lectures on Mathematics in the Life Sciences 17. Ann Arbor: American Mathematical Society.

Thomasson, J.R. 1978. Epidermal patterns of the lemma in some fossil and living grasses and their phylogenetic significance. Science 199: 975-977. 
Thomasson, J.R. 1980. Paleoeriocoma (Gramineae, Stipeae) from the Miocene of Nebraska: Taxonomic and phylogenetic significance. Syst. Bot. 5: 233-240.

Thomasson, J.R. 1981. Micromorphology of the lemma in Stipa robusta and Stipa viridula (Gramineae: Stipeae): Taxonomic significance. S. W. Naturalist 26: 211-214.

Thomasson, J.R. 1982. Fossil grass anthoecia and other plant fossils from arthropod burrows in the Miocene of Western Nebraska. J. Paleontol. 56: 1011-1017.

Thomasson, J.R.1985. Miocene fossil grasses: Possible adaptation in reproductive bracts (lemma and palea). Ann. Missouri Bot. Gard. 72: $843-851$

Thomasson, J.R. 1986. Lemma epidermal features in the North American species of Melica and selected species of Briza, Catabrosa, Glyceria, Neostapfia, Pleuropogon, and Schizachne (Gramineae). Syst. Bot. 11: 253-262.

Thomasson, J.R. 1987. Fossil grasses: 1820-1986 and beyond. Pp. 159-167 in: Soderstrom, T.R., Hilu, K.W., Campbell, C.S. \& Barkworth, M.E. (eds.), Grass systematics and evolution. Washington, D.C.: Smithsonian Institution Press.

Thomasson, J.R. 2005. Berriochloa gabeli and Berriochloa huletti (Gramineae, Stipeae), two new grass species from the late Miocene Ash Hollow Formation of Nebraska and Kansas. J. Paleontol. 79: 185-199.

Torres, A.M. 1997a. Nassella (Gramineae) del noroeste de la Argentina. Comis. Invest. Ci. (Buenos Aires) 13: 5-45.

Torres, A.M. 1997b. Stipa (Gramineae) del noroeste de la Argentina. Comis. Invest. Ci. (Buenos Aires) 13: 46-67.

Torres, A.M. 1997c. Nicoraella (Gramineae) un nuevo genero para America del Sur. Comis. Invest. Ci. (Buenos Aires) 13: 69-77.

Tzvelev, N.N. 1974. Zametki o tribe Stipeae Dum. semeistva zlakov (Poaceae) V SSSR. (Notes of the tribe Stipeae Dum., Fam. Poaceae) in URSS). Novosti Sist. Vyssh. Rast. 11: 4-21.

Tzvelev, N.N. 1976. Zlaki SSSR. Leningrad: Nauka Publishers.

Tzvelev, N.N. 1977. [On the origin and evolution of Feathergrasses (Stipa L.)]. Pp. 139-150 in: Lebedev, D.V. \& Karamysheva, Z.V. (eds.), Problemy ekologii, geobotaniki, botanicheskoi geografii i floristiki. Leningrad: Academiya Nauk SSSR.

Tzvelev, N.N. 1989. The system of grasses (Poaceae) and their evolution. Bot. Rev. (Lancaster) 55: 141-203.
Valdes-Reyna, J. \& Hatch, S.L. 1991. Lemma micromorphology in the Eragrostideae (Poaceae). Sida 14: 531-549.

Vázquez, F.M. \& Barkworth, M.E. 2004. Resurrection and emendation of Macrochloa (Gramineae: Stipeae). Bot. J. Linn. Soc. 144: 483-495.

Vázquez, F.M \& Devesa, J.A. 1996. Revisión del género Stipa L. y Nassella Desv. (Poaceae) en la Península Ibérica e islas Baleares. Acta Bot. Malac. 21: 125-189.

Wang, R., Cheng, C., Chang, C., Wu, C., Su, T. \& Chaw, S.M. 2008. Dynamics and evolution of the inverted repeat-large single copy junctions in the chloroplast genome of monocots. B. M. C. Evol. Biol. 8: 36. DOI: 10.1186/1471-2148-8-36.

Watson, L. \& Dallwitz, M.J. 1992 onwards. The grass genera of the world: Descriptions, illustrations, identification, and information retrieval; including synonyms, morphology, anatomy, physiology, phytochemistry, cytology, classification, pathogens, world and local distribution, and references. Version: 23 Apr. 2010. http:// delta-intkey.com/grass/index.htm.

Wei, F., Coe, E., Nelson, W., Bharti, A.K., Engler, F., Butler, E., Kim, H., Goicoechea, J.L., Chen, M., Lee, S., Fuks, G., Sanchez-Villeda, H., Schroeder, S., Fang, Z., McMullen, M., Davis, G., Bowers, J.E., Paterson, A.H., Schaeffer, M., Gardiner, J., Cone, K., Messing, J., Soderlund, C. \& Wing, R.A. 2007. Physical and genetic structure of the maize genome reflects its complex evolutionary history. PLoS Genet. 3(7): e123. DOI: 10.1371/journal pgen.0030123.

White, T.J., Bruns, T., Lee, S. \& Taylor, J. 1990. Amplifications and direct sequencing of fungal ribosomal RNA genes for phylogenetics. Pp. 315-322 in: Innis, M., Gelfand, D., Sninsky, J. \& White, T. (eds), PCR protocols: A guide to methods and applications. San Diego: Academic Press.

Wu, Z. \& Phillips, S.M. 2006. Stipeae. Pp. 188-212 in: Wu, Z., Raven, P.H. \& Hong, D.Y. (eds.), Flora of China, vol. 22, Poaceae. Beijing: Science Press; St. Louis: Missouri Botanical Garden Press.

Zwickl, D.J. 2006. Genetic algorithm approaches for the phylogenetic analysis of large biological sequence datasets under the maximum likelihood criterion. Ph.D. dissertation, University of Texas, Austin, U.S.A. 